\title{
Cyclin D1-mediated inhibition of repair and replicative DNA synthesis in human fibroblasts
}

\author{
Michele Pagano, Anne M. Theodoras, Sun W. Tam, and Giulio F. Draetta \\ Mitotix Incorporated, Cambridge, Massachusetts 02139 USA
}

\begin{abstract}
Cyclin D1 is a key regulator of the $G_{1}$ phase of the cell cycle. Inhibition of cyclin D1 function results in cell cycle arrest, whereas unregulated expression of the protein accelerates $G_{1}$. Cyclin D1 is localized to the nucleus during $G_{1}$. We found that during repair DNA synthesis, subsequent to UV-induced DNA damage, $G_{1}$ cells readily lost their cyclin D1 while the proliferating cell nuclear antigen (PCNA) tightly associated with nuclear structures. Microinjection of cyclin D1 antisense accelerated DNA repair, whereas overexpression of cyclin D1 prevented DNA repair and the relocation of PCNA after DNA damage. Coexpression of cyclin D1 with its primary catalytic subunit, $\mathrm{Cdk} 4$, or with $\mathrm{Cdk2}$, also prevented repair. In contrast, coexpression of PCNA, which is also a cyclin D1-associated protein, restored the ability of cells to repair their DNA. Acute overexpression of cyclin D1 in fibroblasts prevented them from entering S phase. Again, these effects were abolished by coexpression of cyclin D1 together with PCNA, but not with Cdk4 or Cdk2. Altogether, these results indicate that down-regulation of cyclin D1 is necessary for PCNA relocation and repair DNA synthesis as well as for the start of DNA replication. Cyclin D1 appears to be an essential component of a $\mathbf{G}_{\mathbf{1}}$-checkpoint.
\end{abstract}

[Key Words: Cyclin D1; DNA replication; PCNA; DNA repair]

Received April 12, 1994; revised version accepted May 31, 1994.

In mammalian cells, a family of serine/threonine protein kinases, the cyclin-dependent kinases (Cdks) and their regulatory subunits, called cyclins, regulate the cell division cycle. Progression through the $G_{1}$ phase represents a critical cell cycle step in which cyclin D1 has been strongly implicated (for review, see Sherr 1993).

Inhibition of cyclin D1 function results in cell cycle arrest (Baldin et al. 1993; Quelle et al. 1993), whereas a moderate overexpression of the protein accelerates $G_{1}$ (Jiang et al. 1993; Quelle et al. 1993; Resnitzky et al. 1994). Synthesis of cyclin D1 mRNA and protein peaks during mid- $G_{1}$. As cells progress into $S$ phase, it decreases (Matsushime et al. 1991a,b; Motokura et al. 1991, 1992; Won et al. 1992; Baldin et al. 1993; Musgrove et al. 1993; Sewing et al. 1993; Winston and Pledger 1993; Lukas et al. 1994a,c) and the protein disappears from the nucleus (Baldin et al. 1993; Lukas et al. 1994a,c).

Cyclin D1 associates in vivo with Cdc2 (Cdk1), Cdk2, Cdk4, Cdk5, and Cdk6 (Matsushime et al. 1992; Xiong et al. 1992; Zhang et al. 1993; Bates et al. 1994; Meyerson and Harlow 1994), but only Cdk4 and Cdk6 have been demonstrated to form catalytically active complexes with D cyclins in vivo (Dulic et al. 1993; Ewen et al. 1993b; Kato et al. 1993; Tsai et al. 1993b; Bates et al. 1994; Matsushime et al. 1994; Meyerson and Harlow 1994; Tam et al. 1994). The cyclin Dl-Cdk4 complex associates with the $\mathrm{p} 21$ inhibitor /also called Cip1, Waf1, Sdil; Xiong et al. 1992, 1993b; El-Deiry et al. 1993; Gu et al. 1993; Harper et al. 1993; Zhang et al. 1993; Noda et al. 1994), an important mediator of p53-dependent growth suppression (El-Deiry et al. 1993; Xiong et al. 1993b; Dulic et al. 1994). A distinct polypeptide, $\mathrm{pl}^{\text {Ink4 }}$, has been shown to selectively inhibit cyclin D1-Cdk4 kinase activity in vitro (Serrano et al. 1993). The association of cyclin D1 with Cdk4 is required to stimulate progression through the $G_{1}$ phase of the cell cycle (Tam et al. 1994). However, the possibility that cyclin D1 might have a function in $G_{0} / G_{1}$ independent of its association with Cdk4 is suggested by the recent observation that in cells arrested by transforming growth factor- $\beta$ (TGF- $\beta$ ) treatment (Ewen et al. 1993a) the cyclin D1 levels remain high but Cdk4 levels became undetectable. Furthermore, in senescent cells (Dulic et al. 1993; Lucibello et al. 1993) Cdk4 is not present, whereas cyclin D1 is synthesized continuously. Finally, an elevation in cyclin D1 abundance, in the absence of Cdk4, is observed in cells undergoing apoptosis in a p53-independent manner (Freeman et al. 1994).

Cyclin D1 has been found also to associate with proliferating cell nuclear antigen (PCNA) (Xiong et al. 1992), the auxiliary protein of DNA polymerases $\delta$ and $\epsilon$, required for DNA replication (Bravo and Macdonald-Bravo 1987; Bravo et al. 1987; Prelich et al. 1987a,b; Jaskulski 
et al. 1988) and repair (Celis and Madsen 1986; Lee et al. 1991, 1992; Shivji et al. 1992). Cyclin D1 and PCNA can bind together directly, without the requirement of other cellular factors (Matsuoka et al. 1994). Cyclin D1 is localized to the nucleus during the $G_{1}$ phase of the cell cycle in both normal (Baldin et al. 1993) and transformed (Lukas et al. 1994c) human cells. Similar results have been obtained in mouse fibroblasts using monoclonal antibodies that specifically recognize cyclin D1, but not cyclin D2 or D3 (A. Theodoras and M. Pagano, unpubl.). In contrast, PCNA is nuclear both during $G_{1}$ and $S$ phase. While in $G_{1}$, PCNA is easily extracted with nonionic detergents; in S phase or after UV irradiation, it is tightly bound to DNA /Celis and Madsen 1986; Toschi and Bravo 1988).

In this report we investigated the function of cyclin D1 in relationship with repair and replicative DNA synthesis by examining the effects of either inhibiting or overexpressing cyclin D1 in human $G_{1}$ fibroblasts.

\section{Results \\ Cyclin D1 disappearance from $U V$-irradiated $G_{1}$ fibroblasts}

During $G_{1}$, PCNA can be readily extracted from the nucleus using nonionic detergents, such as Triton X-100, (Bravo and Macdonald-Bravo 1987; Celis et al. 1987; Waseem and Lane 1990), whereas during S-phase or in cells undergoing DNA repair following UV irradiation, a fraction of the total PCNA becomes tightly bound to the nucleus (Triton nonextractable) (Celis and Madsen 1986; Toschi and Bravo 1988). Because cyclin D1 has been found to bind PCNA (Xiong et al. 1992; Matsuoka et al. 1994), we decided to investigate the localization of cyclin D1 upon UV-induced DNA damage in $\mathrm{G}_{1}$ cells. Human diploid lung IMR-90 fibroblasts were made quiescent by serum deprivation. The arrested cells were stimulated by serum readdition and processed for immunofluorescence $13.5 \mathrm{hr}$ after reactivation, when $\sim 95 \%$ of the cells are in $G_{1}$ (data not shown; Baldin et al. 1993; Pagano et al. 1993; Tam et al. 1994). Cyclin D1 (Fig. $1 \mathrm{~A}, \mathrm{C}, \mathrm{O})$ and another well-characterized $\mathrm{G}_{1}$ cyclin, cyclin E (Koff et al. 1991; Lew et al. 1991) (Fig. 1I,K) were localized to the nucleus and, similarly to PCNA (Fig. $1 \mathrm{E}, \mathrm{G})$, could be extracted by pretreatment with Triton $\mathrm{X}-100$. We also irradiated $\mathrm{G}_{1}$ cells $(12 \mathrm{hr}$ after serum readdition) with UV light $\left(75 \mathrm{~J} / \mathrm{m}^{2}\right)$ and then cultured them for an additional $90 \mathrm{~min}$, prior to fixing and immunostaining. Following irradiation, the cyclin D1 signal disappeared rapidly from both the Triton-extracted (Fig. 1D) and the untreated cells (Fig. 1B,P), whereas PCNA (Fig. 1F,H) and cyclin E (Fig. 1J,L) became resistant to extraction. Repair DNA synthesis, after UV irradiation, was monitored by bromodeoxyuridine (BrdU) incorporation (Fig. $1 \mathrm{M}, \mathrm{N}$ ) and distinguished from replicative DNA synthesis as described in Materials and methods.

We also analyzed the accumulation of cyclin D1, cyclin E, and PCNA by immunoblotting at various times after the fibroblasts had been stimulated to reenter the cell cycle (Fig. 2). Cells were fractionated in Triton-soluble and -insoluble extracts. Following serum readdition, a greater increase in the abundance of the three proteins was observed in the Triton-insoluble fractions than in the Triton-soluble fractions, indicating that as cells progress through the $G_{1}$ phase of the cell cycle, subpopulations of cyclin D1, cyclin E, and PCNA become tightly associated with nuclear structures. When we irradiated quiescent cells with UV light $\left(75 \mathrm{~J} / \mathrm{m}^{2}\right)$ and followed the accumulation of cyclin D1, cyclin E, and PCNA after serum readdition, we found that cyclin Dl failed to accumulate, whereas a substantial fraction of the total PCNA and cyclin E became resistant to extraction (cf. 0 and $4 \mathrm{hr}+\mathrm{UV}$ to 0 and $4 \mathrm{hr}-\mathrm{UV}$ in the Triton-insoluble fractions). Furthermore, cyclin D1 disappeared quickly from cells treated with UV light during $\mathrm{G}_{1}$ (Fig. 2, G1 -, +1 in contrast to PCNA and cyclin E, which increased in the Triton-insoluble fractions of these cells. Interestingly, $\mathrm{pRb}$, a substrate of both cyclin $\mathrm{D}$ and cyclin E kinases (for review, see Sherr 1994), became hypophosphorylated upon irradiation (Fig. 2, right and left bottom).

As shown previously for PCNA (Toschi and Bravo 1988), the effects increased with UV doses ranging from 0 to $75 \mathrm{~J} / \mathrm{m}^{2}$ (Fig. 3A). A direct relationship between cyclin D1 disappearance and PCNA relocation was found. Under the same conditions, we also monitored the levels of cyclin E (Fig. 3B), and p53 and p21 (Fig. 3C), which are known to increase in abundance in response to DNA damage. In the irradiated cells the abundance of cyclin $\mathrm{E}$ did not change dramatically. Cyclin E kinase activity (Fig. 3B) was instead inhibited at low doses $(5-25$ $\left.\mathrm{J} / \mathrm{m}^{2}\right)$, whereas at high UV doses $\left(50-75 \mathrm{~J} / \mathrm{m}^{2}\right)$ it was still detectable with an increase of up twofold compared with control. Activation of cyclin E kinase at high UV doses correlated with the appearance of the hyperphosphorylated form of cyclin E (Dulic et al. 1992, 1994) (Fig. 2). p53 appeared to be entirely Triton-extractable, and its abundance reached a peak at $25 \mathrm{~J} / \mathrm{m}^{2}$; but, as described previously (Lu and Lane 1993), it was not induced at higher doses. Similar results were obtained for $\mathrm{p} 21$, the expression of which is directly induced by p53 (El-Deiry et al. 1993; Harper et al. 1993; Xiong et al. 1993b; Dulic et al. 1994). Interestingly, a substantial fraction of $\mathrm{p} 21$ was not detergent-extractable. Thus, the inhibition of cyclin $\mathrm{E}$ kinase activity correlated precisely with the appearance of nonextractable p21.

\section{Cyclin D1 overexpression inhibits DNA repair and PCNA relocation}

The disappearance of cyclin D1 and the concomitant redistribution of PCNA during DNA repair prompted us to test the effects of cyclin D1 overexpression during repair. Quiescent or $G_{1}$ cells (1-2 hr after serum readdition) were injected with a cyclin D1 expression vector $(\mathrm{pX}-$ D1). Six to $12 \mathrm{hr}$ after serum readdition, cells were irradiated with $75 \mathrm{~J} / \mathrm{m}^{2}$ of UV light, cultured for 1 (A to F) or 8 ( $\mathrm{G}$ to $\mathrm{L}$ ) additional hours, Triton-treated, fixed, and 

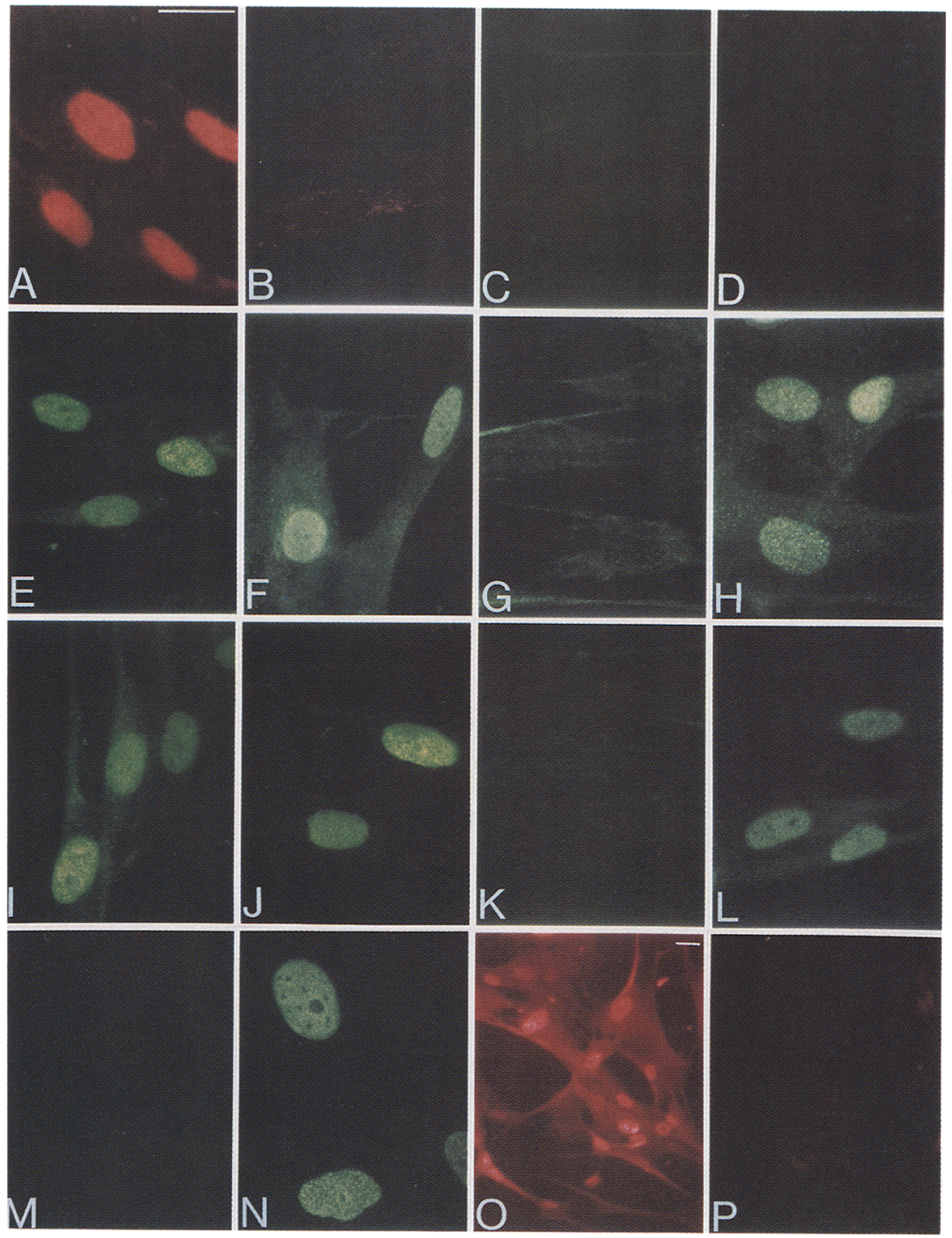

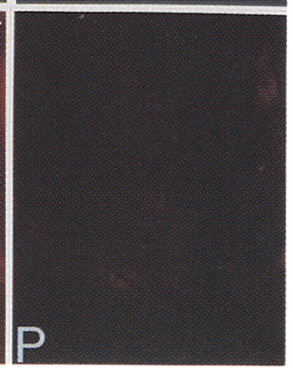

Figure 1. Nuclear accumulation of cyclin D1 and PCNA in human fibroblasts. Human fibroblasts were rendered quiescent by serum starvation and then synchronized in $\mathrm{G}_{1}$ by serum readdition for a period of 13.5 hr. Cells in $B, D, F, H, I, L, N$, and $P$ were UV irradiated $\left(75 \mathrm{~J} / \mathrm{m}^{2}\right) 12 \mathrm{hr}$ after serum readdition and then cultured for 90 additional min. $(A-D, O, P\}$ cyclin D1 staining; $(E-H)$ PCNA staining; $(I-L)$ cyclin E staining; $(C, D, G, H, K, L)$ cells extracted in situ with $0.1 \%$ Triton prior to fixation. $\langle A, B, E$, $F, I, J, M-P)$ Non-Triton-treated cells; $(M-N)$ : BrdU staining. Pairs $A-B$ and $O-P$ represent the same condition but different magnifications. Bars in $A$ and $O, 10 \mu \mathrm{m}$. immunostained (Fig. 4). Cells injected with pX-D1 (Fig. 4A-C, G-I), but not control injected cells (Fig. 4D-F, I-L), were unable to undergo repair nor was PCNA relocation observed. One interpretation of these results is that the overproduced cyclin D1 sequestered PCNA and prevented DNA repair. To test this hypothesis, we coinjected the $\mathrm{pX}-\mathrm{D} 1$ plasmid together with a PCNA expression vector ( $\mathrm{pX}-\mathrm{PCNA})$. As controls, we injected $\mathrm{pX}-$ PCNA alone or expression vectors for $\mathrm{Cdk} 4$ or $\mathrm{Cdk} 2$, two other cyclin D1-associated proteins, either alone or in combination with $\mathrm{pX}-\mathrm{D} 1$. The expression of PCNA, $\mathrm{Cdk} 2$, or Cdk4 alone did not result in inhibition of repair (Table 1). Significantly, coexpression of cyclin D1 with PCNA, but not with Cdk4 or Cdk2, resulted in a $>50 \%$ reduction in the inhibition of DNA repair induced by cyclin D1 overexpression (Table 1). Expression of cyclin D1, PCNA, Cdk2, and Cdk4 in $\sim 60-70 \%$ of the injected cells and their nuclear localization was demonstrated by immunofluorescence (data not shown). Interestingly, although in no case cells survived the $75 \mathrm{~J} / \mathrm{m}^{2}$ dose of UV, the survival time was shortened in $\mathrm{pX}-\mathrm{D} 1$-injected cells; $8 \mathrm{hr}$ after irradiation, $\sim 40 \%$ of the cells had undergone apoptotic death (A. Theodoras, M. Pagano and G. Draetta, unpubl.).

\section{Antisense cyclin D1 microinjection accelerates DNA repair}

Because overexpression of cyclin D1 leads to a failure in DNA repair, we tested whether inhibition of cyclin D1 expression affected DNA repair activity. In Figure 5, the result of a typical microinjection experiment is shown. $\mathrm{G}_{1}$ cells (1-4 hr after serum readdition) were injected with pX-D1 antisense vector (Baldin et al. 1993), together with a microinjection marker (rabbit IgG). Six to 8 hr after microinjection, cells were UV irradiated, incu- 
Figure 2. Cyclin Dl disappears from $\mathrm{G}_{1}$-fibroblasts undergoing DNA repair. Proteins (25-50 $\mu \mathrm{g} /$ lane) from the Triton-soluble (left) and the Triton-insoluble fractions (right) of cells reactivated by serum readdition and sampled at 4-hr intervals after starvation for $48 \mathrm{hr}$ (lanes 1-8, 11-18| were separated by SDS-PAGE, transferred from gel to a PVDF membrane, and immunoblotted with the antibodies to the indicated proteins. Where indicated, cells were UV irradiated $\left(75 \mathrm{~J} / \mathrm{m}^{2}\right)$ before reactivation (lanes $5-8,15-18$ ) or irradiated $12 \mathrm{hr}$ after reactivation and reincubated for 90 additional $\min |\mathrm{G} l|+\mid$ lanes 10,20]. G1 (-) indicates extract from cell reactivated for $13.5 \mathrm{hr}$.

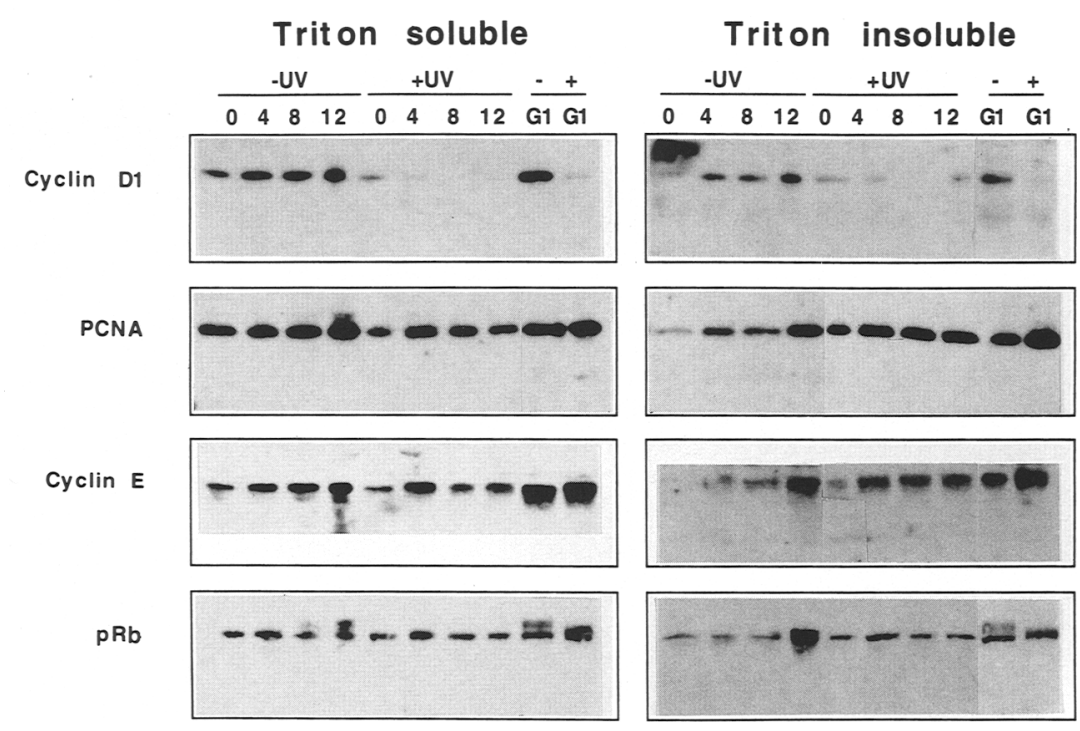

bated with BrdU to monitor DNA repair, fixed $2 \mathrm{hr}$ later, and stained. BrdU incorporation was readily detectable in $65-70 \%$ of the cyclin D1-injected cells $(\mathrm{A}-\mathrm{C})$, whereas only $5-15 \%$ of the noninjected cells or cells injected with control vector showed BrdU incorporation. A signal comparable to the one observed in antisense injected cells was obtained in $100 \%$ of mock-injected cells (not shown) and in noninjected cells (Fig. 1N) by extending the incubation with BrdU for at least 2 additional hr.

\section{Cyclin D1 overexpression inhibits DNA replication but not cell division}

We tested whether cyclin D1 overexpression was also able to prevent DNA replication. Cells were microinjected in early $G_{1}$ with the pX-D1 expression plasmid. We found that the injected cells never entered $S$ phase. The effect was dramatic and quantitative (Table 2). The block seemed to occur late in $G_{1}$, because the arrested cells expressed nuclear cyclin A (data not shown), which normally appears $12-16 \mathrm{hr}$ after serum readdition, but they could not incorporate BrdU. This $\mathrm{G}_{1}$ arrest could be caused by the competition between the overexpressed free cyclin D1 and the complexed cyclin D1 for intracellular target recognition. Alternatively, proteins normally bound to cyclin D1 in $G_{1}$, and then released as cells enter $\mathrm{S}$ phase, might fail to be dissociated upon cyclin D1 overexpression. We therefore tested whether overexpression of Cdk4, Cdk2, or PCNA could prevent the inhibition of $S$ phase observed upon injection of cyclin D1 vector. A further complex component, p21, was not tested because alone, it inhibits the cyclin-dependent kinases and causes cell cycle arrest (El-Deiry et al. 1993; Gu et al. 1993; Harper et al. 1993; Xiong et al. 1993b; Dulic et al. 1994). Although neither Cdk2 or Cdk4 overexpression could rescue the cyclin D1-overexpressing cells, PCNA fully restored the ability of those cells to enter $S$ phase. Interestingly, injection of $\mathrm{pX}-\mathrm{D} 1$ in two different lines of SV40 immortalized human lung fibroblasts synchronized in $\mathrm{G}_{1}$ [IMR-90+LT (Tam et al. 1994) and WI-38-VA-13 (Xiong et al. 1993a)] did not affect entry into $S$ phase (Table 2).

To test whether the overexpression of cyclin D1 was inhibiting DNA synthesis specifically, $\mathrm{G}_{2}$ cells $(28 \mathrm{hr}$ after reactivation/ were injected with $\mathrm{pX}-\mathrm{D} 1$ or control vector. No inhibition of mitosis and cytokinesis was observed (Table 3), demonstrating that the cell cycle arrest caused by cyclin $\mathrm{D} 1$ overexpression is restricted to a specific point in the cell cycle. As reported previously, cells injected with rabbit anti-cyclin $\mathrm{A}$ antibody did not divide (Pagano et al. 1992b) (Table 3).

\section{Discussion}

In this paper we analyzed the functional relationship between cyclin D1 and DNA synthesis, either replicative or repair, in human $G_{1}$ fibroblasts. The disappearance of cyclin D1 from the nucleus of cells undergoing replicative (Baldin et al. 1993; Lukas et al. 1994c) or repair DNA synthesis, together with the inhibition of DNA synthesis by cyclin D1 overexpression and the acceleration of repair induced by lack of cyclin Dl, supports the existence of a causal relationship between the nuclear disappearance of cyclin Dl and the occurrence of DNA synthesis (Fig. 6).

After DNA damage induced by high doses of UV light, cessation of replicative synthesis is accompanied by high levels of repair synthesis. Examination of cell extracts 2 $\mathrm{hr}$ after this UV treatment shows that cyclin D1 disappears, PCNA becomes tightly associated with nuclear structures, p53 and p21 are not induced, and cyclin E kinase activity is present. From this point of view, the $\mathrm{G}_{1}$ block induced by high doses of UV light differs from the one induced by ionizing radiation, where neither unscheduled DNA synthesis [(Lu and Lane 1993) but also see Kastan et al. (1991, 1992); Datta et al. (1992); Kuerbitz et al. (1992); Muschel et al. (1993); Dulic et al. (1994)] nor disappearance of cyclin D1 is detected (Dulic 


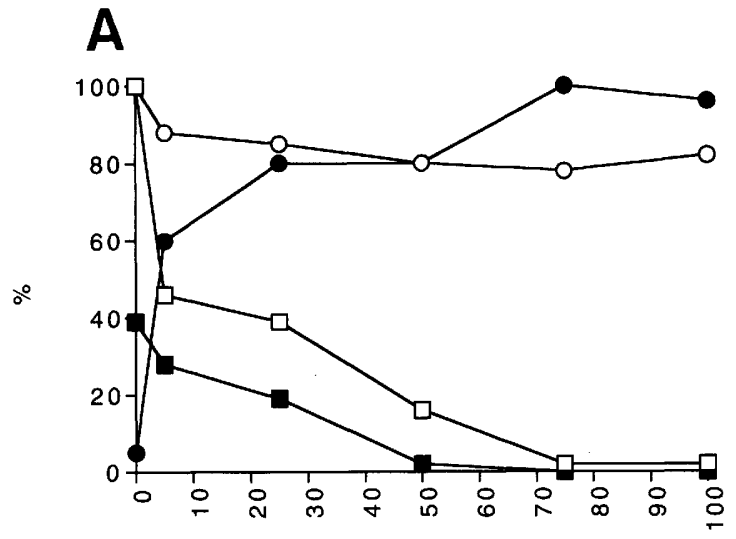

UV dose $\left(\mathrm{J} / \mathrm{m}^{2}\right)$

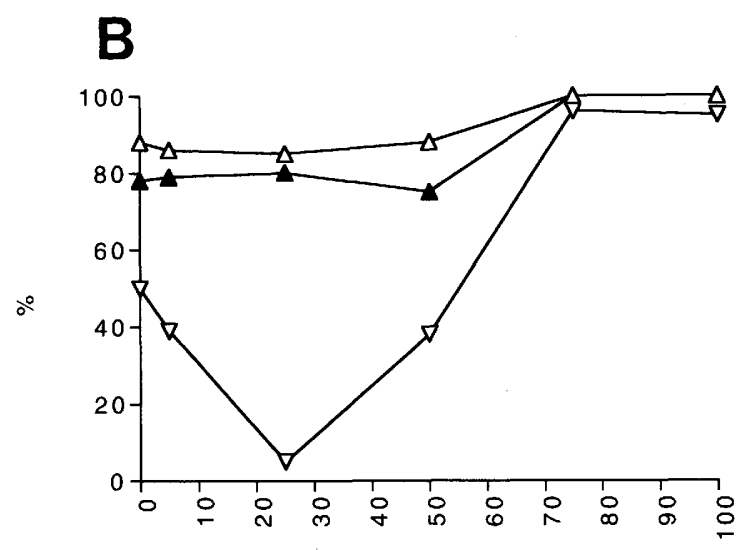

UV dose $(\mathrm{J} / \mathrm{m} 2)$

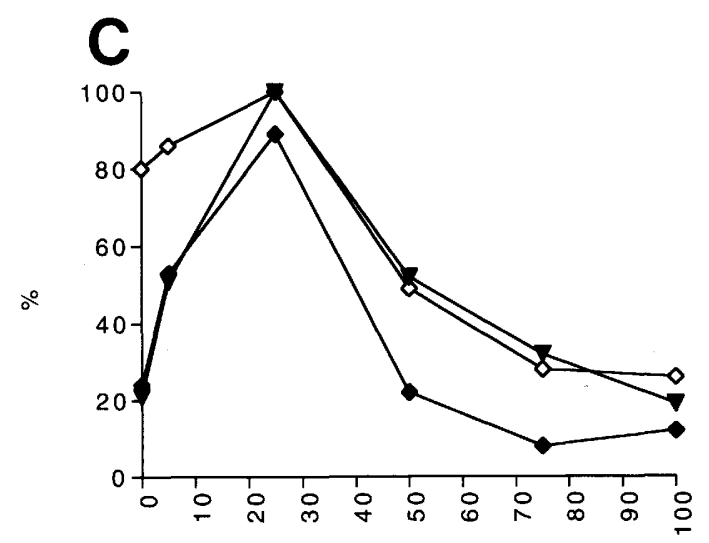

UV dose $(\mathrm{J} / \mathrm{m} 2)$

et al. 1994). Ionizing radiation causes a $\mathrm{G}_{1}$ arrest via $\mathrm{p} 53$ mediated induction of $\mathrm{p} 21$, which inhibits cyclin $\mathrm{E}$ and cyclin D1 pRb kinase activities (Dulic et al. 1994). In contrast, during repair DNA synthesis induced by high doses of UV light, cyclin E activity is still present (both p53 and p21 are not induced) and presumably needed for the phosphorylation of key substrates (e.g., replication factors) involved in DNA synthesis. Nevertheless, S
Figure 3. Dose-response curve of cyclin Dl and PCNA accumulation following UV irradiation. $(A)$ Cyclin D1 disappearance and PCNA relocation occur in parallel. ( $\square$ ) Cyclin D1 Triton soluble; ( $\mathbf{(})$ cyclin D1 Triton insoluble; (O) PCNA Triton soluble; (O) PCNA Triton insoluble. Dose-response curve of cyclin $\mathrm{E}$ abundance and cyclin $\mathrm{E}$ kinase activity $(B)$ and $\mathrm{p} 53$, and p21 abundance $(C)$ following UV irradiation: p53 and p21 induction and cyclin $E$ kinase activity are inversely correlated. $(B)(\Delta)$ Cyclin E Triton soluble; $(\mathbf{\Delta}$ ) cyclin E Triton insoluble; $(\nabla)$ cyclin E kinase. $(C)(\nabla)$ p53 Triton soluble; $|\diamond|$ p21 Triton soluble; $|\diamond|$ p21 Triton insoluble. Human fibroblasts were rendered quiescent by serum starvation and then stimulated to re-enter the cell cycle by serum readdition. Twelve hours after reactivation, cells were UV irradiated with the indicated doses, incubated further at $37^{\circ} \mathrm{C}$ for 120 additional min, and lysed. Triton soluble and Triton insoluble extracts were immunoblotted with antibodies to the indicated proteins. Duplicate autoradiograms were scanned and results were plotted as percentage of the maximum value obtained for each protein in the Triton soluble or the Triton insoluble cellular fractions. Cyclin E histone $\mathrm{Hl}$ kinase activity was measured in the Triton soluble fraction as described in Materials and methods.

phase is blocked by the lack of $\mathrm{pRb}$ phosphorylation (Fig. 2 ) and cyclin A kinase activity (data not shown).

The inverse relationship between cyclin D1 and DNA replication suggests that cyclin D1 plays two different functions during $G_{1}$ : (1) It stimulates $G_{1}$ progression /via the association with its catalytic partner Cdk4 and the consequent phosphorylation of key substrates), and (2) it ensures that DNA synthesis does not occur prematurely. Cell cycle progression is monitored by a network of feedback controls or "checkpoints" that preclude specific events in the absence of successful completion of preceding ones. During the $G_{1}$ phase of the cell cycle, cells need to monitor nutritional/ambient conditions, cellular size, and so forth, before committing to DNA replication. This decision point is known as Start in yeast (Hartwell 1974) and as restriction point (R) in mammalian cells (Pardee 1989). Our results provide evidence for a role of a $G_{1}$ cyclin in checkpoint control in mammalian cells. The fact that PCNA is the only component of the cyclin D1 complex able to prevent inhibition of DNA synthesis by cyclin D1 suggests that cyclin D1 exercises its inhibitory function in $G_{1}$ by keeping PCNA in an inactive form. In agreement with this hypothesis, it has been shown that cyclin D1 and PCNA can form a complex in the absence of other cellular factors (Matsuoka et al. 1994) and that cyclin DI and PCNA are present at similar levels in $\mathrm{G}_{1}$ diploid human fibroblasts (S. Wick and $M$. Pagano, unpubl.). The nuclear cyclin D1-PCNA complex (Xiong et al. 1992) could prevent, during $G_{1}$, the formation of Cdk2-cyclin E-PCNA and Cdk2-cyclin A-PCNA complexes and/or their interaction with the DNA replication apparatus (Blow and Nurse 1990; D'Urso et al. 1990; Dutta et al. 1991; Fang and Newport 1991; Fotedar and Roberts 1991; Girard et al. 1991; Lehner et al. 1991; Dutta and Stillman 1992; Pagano et al. 1992b, 1993; Xiong et al. 1992; Zindy et al. 1992; Cardoso et al. 1993; Guadagno et al. 1993; Ohtsubo and 


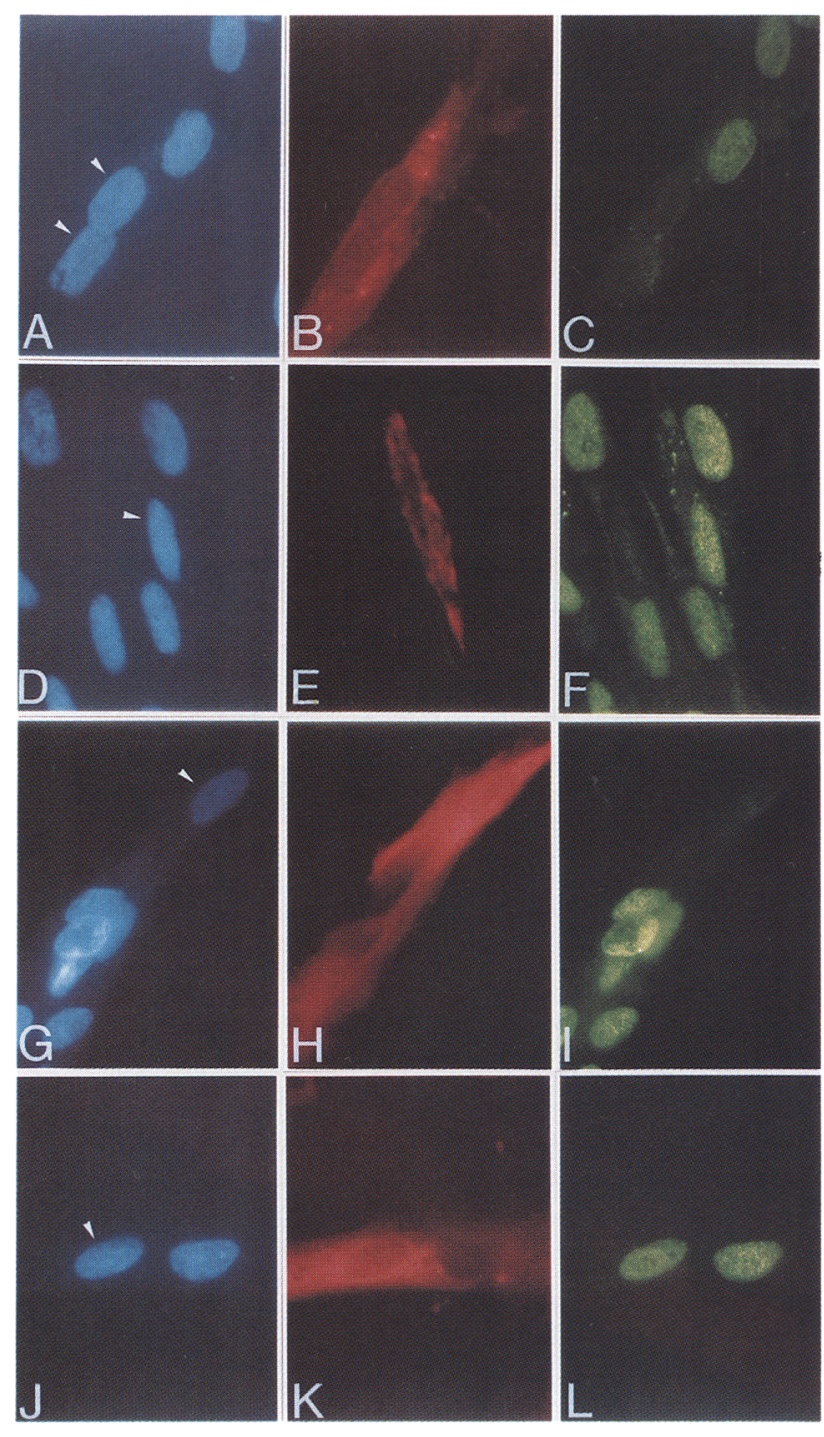

Figure 4. Cyclin Dl overexpression inhibits PCNA relocation and DNA repair. $\mathrm{pX}-$ cyclin $\mathrm{D} 1$ vector plasmid $(A-C, G-I)$ or $\mathrm{pX}$ control vector $(D-F, I-L)$ were injected in $\mathrm{G}_{0}$ cells together with normal affinity-purified rabbit antibody $3 \mathrm{mg} / \mathrm{ml}$ in PBS used as a microinjection marker). Cells were reactivated by serum readdition and UV irradiated 6-12 hr later. After $1(A-F)$ or 8 $(G-L)$ additional hr of incubation at $37^{\circ} \mathrm{C}$, cells were processed for immunofluorescence. $(A-F)$ Cells pre-extracted with Triton $\mathrm{X}-100 ;(A, D, G, I)$ Hoechst staining; $(B, E, H, K)$ detection of injected marker antibodies with Texas red-conjugated goat antirabbit antibodies; $(C, F)$ PCNA detection; $(I, L)$ BrdU detection. Arrowheads in $A, D, G$, and $/$ indicate the position of the injected cells shown respectively in $B, E, H$, and $K$.

Roberts 1993; Sobczak-Thepot et al. 1993; Tsai et al. 1993a; van den Heuvel and Harlow 1993; Zhang et al. 1993). Recent experimental evidence, suggesting that $\mathrm{G}_{1}$ - and S-phase cyclins play opposing roles, supports our model. E2F-1 is trans-activated by cyclin D1 (A. Schulze, K. Zerfass, D. Spitkovsky, J. Berges, P. Jansen-Dürr, and B. Henglein, in prep.) in $G_{1}$ and inactivated by cyclin $A$ in $S$ phase (D. Livingston, pers. comm.) and cyclin D1 inhibits T antigen-mediated replication of SV40 DNA in a HeLa extract, whereas cyclin A stimulates the reaction (A. Amin and J. Hurwitz, pers. comm.). It has been shown that cyclin D1 cannot activate Cdk2, whereas cyclin A can (Kato et al. 1993). From this perspective, cyclin D1 could be considered both as a "true" cyclin, which binds and activates Cdk4 (Kato et al. 1993; Matsushime et al. 1992, 1994; Tam et al. 1994), and as an "anti-cyclin," which binds only the dephosphorylated/ inactive form of Cdk2 (Dulic et al. 1993; Kato et al. 1993; Bates et al. 1994).

It has not been possible to establish cell lines that express high levels of cyclin D1. Quelle et al. (1993), while attempting to stably overexpress cyclin Dl from strong promoters, found a significant decrease in the number of drug-resistant colonies compared with those obtained with control vectors alone and no elevated cyclin D1 protein levels in the cyclin D1-transfected survivors. In contrast, stable moderate overexpression of cyclin D1, at levels five to eightfold above normal, accelerates the $G_{1}$ phase (Jiang et al. 1993; Quelle et al. 1993; Resnitzky et al. 1994). During both replicative and repair DNA synthesis, cyclin D1 disappears from the nuclei of mouse fibroblasts engineered to stably overexpress such moderate amounts of cyclin D1 (A. Theodoras, M. Pagano, M. Roussel, and C. Sherr, unpubl.). Thus, even in conditions in which synthesis of ectopic cyclin Dl is not subjected to normal regulation, the protein is excluded from the nucleus as cells undergo DNA synthesis. Our results, showing that acute overexpression of cyclin Dl does not allow exit from $G_{1}$ and that its degradation is necessary for DNA repair and PCNA relocation, suggest that turnover of a $G_{1}$ cyclin is essential for regulated cell cycle progression in mammalian cells. Just as cells need to inactivate the cyclin $\mathrm{B}-\mathrm{Cdc} 2$ kinase to exit $\mathrm{M}$ phase (Draetta et al. 1989; Murray et al. 1989; Glotzer et al. 1990; Luca et al. 1991; Gallant and Nigg 19921, they might need to inactivate the cyclin D1-Cdk4 complex and dissociate the complex that cyclin Dl forms with PCNA to leave $G_{1}$ and enter $S$ phase.

It has been shown that cyclin Dl can function as an oncogene (Jiang et al. 1993; Hinds et al. 1994; Lovec et al. 1994). Although a variety of tumor cell lines have been found to carry cyclin D1 gene amplification and mRNA overexpression (for review, see Motokura and Arnold 1993), cyclin D1 protein in these cells is never dramatically overexpressed (Lukas et al. 1994c). In contrast, all tumor cell lines carrying functional inactivation of $\mathrm{pRb}$ show low or undetectable levels of cyclin D1 (Lukas et al. 1994b; Tam et al. 1994). Absence of cyclin Dl checkpoint in $G_{1}$ in these cells and the consequent aberrant control of DNA replication might be responsible, in part, for the genetic instability typically found in neoplasia. Interestingly, we found that in the transformed cells in which cyclin Dl complexes are dissociated (Xiong et al. 1993b), overexpression of cyclin D1 had no effect on cell cycle progression. Thus, we believe that cyclin D1 is a mediator of checkpoint response in normal cells and that loss of this function might be implicated in oncogenic transformation. 
Table 1. Effect of cyclin D1 overexpression on DNA repair

\begin{tabular}{|c|c|c|c|c|c|}
\hline \multirow[b]{2}{*}{ Experiment } & \multirow[b]{2}{*}{ Injected plasmid } & \multicolumn{3}{|c|}{ Injected cells } & \multirow{2}{*}{$\begin{array}{l}\text { Noninjected } \\
\text { cells incorporating } \\
\text { BrdU }(\%)\end{array}$} \\
\hline & & number & $\begin{array}{l}\mathrm{BrdU}^{+} \text {cells } \\
\text { (number) }\end{array}$ & $\begin{array}{l}\text { incorporating } \\
\operatorname{BrdU}(\%)\end{array}$ & \\
\hline \multirow[t]{8}{*}{1} & $\mathrm{pX}-\mathrm{D} 1(50 \mathrm{ng} / \mu \mathrm{l})+$ vector $(50 \mathrm{ng} / \mu \mathrm{l})+$ rabbit $\mathrm{IgG}$ & 112 & 40 & 35.7 & 100.0 \\
\hline & $\mathrm{pX}-\mathrm{Dl}(50 \mathrm{ng} / \mu \mathrm{l})+\mathrm{pX}-\mathrm{PCNA}(50 \mathrm{ng} / \mu \mathrm{l})+\mathrm{rabbit}$ IgG & 130 & 100 & 76.9 & 100.0 \\
\hline & $\mathrm{pX}-\mathrm{D} 1(50 \mathrm{ng} / \mu \mathrm{l})+\mathrm{pX}-\mathrm{Cdk} 2(50 \mathrm{ng} / \mu \mathrm{l})+$ rabbit IgG & 107 & 35 & 32.7 & 100.0 \\
\hline & $\mathrm{pX}-\mathrm{D} 1(50 \mathrm{ng} / \mu \mathrm{l})+\mathrm{pX}-\mathrm{Cdk} 4(50 \mathrm{ng} / \mu \mathrm{l})+$ rabbit IgG & 94 & 23 & 24.4 & 100.0 \\
\hline & $\mathrm{pX}-\mathrm{PCNA}(50 \mathrm{ng} / \mu \mathrm{l})+\operatorname{vector}(50 \mathrm{ng} / \mu \mathrm{l})+$ rabbit $\mathrm{IgG}$ & 136 & 131 & 96.3 & 100.0 \\
\hline & $\mathrm{pX}-\mathrm{Cdk} 4(50 \mathrm{ng} / \mu \mathrm{l})+\operatorname{vector}(50 \mathrm{ng} / \mu \mathrm{l})+$ rabbit IgG & 115 & 109 & 94.7 & 100.0 \\
\hline & $\mathrm{pX}-\mathrm{Cdk} 2(50 \mathrm{ng} / \mu \mathrm{l})+$ vector $(50 \mathrm{ng} / \mu \mathrm{l})+$ rabbit IgG & 126 & 124 & 98.4 & 100.0 \\
\hline & vector $(100 \mathrm{ng} / \mu \mathrm{l}+$ rabbit $\mathrm{IgG})+$ rabbit $\operatorname{IgG}$ & 142 & 140 & 98.6 & 100.0 \\
\hline \multirow[t]{5}{*}{2} & $\mathrm{pX}-\mathrm{D} 1(5 \mathrm{ng} / \mu \mathrm{l})+$ vector $(50 \mathrm{ng} / \mu \mathrm{l})+$ rabbit $\mathrm{IgG}$ & 116 & 46 & 39.6 & 100.0 \\
\hline & $\mathrm{pX}-\mathrm{D} 1(5 \mathrm{ng} / \mu \mathrm{l})+\mathrm{pX}-\mathrm{PCNA}(5 \mathrm{ng} / \mu \mathrm{l})+$ rabbit $\mathrm{IgG}$ & 133 & 101 & 75.9 & 100.0 \\
\hline & $\mathrm{pX}-\mathrm{D} 1\{5 \mathrm{ng} / \mu \mathrm{l})+\mathrm{pX}-\mathrm{PCNA}(50 \mathrm{ng} / \mu \mathrm{l})+$ rabbit IgG & 119 & 86 & 72.2 & 100.0 \\
\hline & $\mathrm{pX}-\mathrm{Dl}\langle 5 \mathrm{ng} / \mu \mathrm{l})+\mathrm{pX}-\mathrm{Cdk} 4(50 \mathrm{ng} / \mu \mathrm{l})+$ rabbit IgG & 101 & 35 & 34.6 & 100.0 \\
\hline & vector $(55 \mathrm{ng} / \mu \mathrm{l})+($ rabbit IgG $)+$ rabbit IgG & 159 & 156 & 98.1 & 100.0 \\
\hline \multirow[t]{2}{*}{3} & $\mathrm{pX}-\mathrm{Dl}(50 \mathrm{ng} / \mu \mathrm{l})+$ vector $(50 \mathrm{ng} / \mu \mathrm{l})$ & 76 & 9 & 11.8 & 100.0 \\
\hline & $\mathrm{pX}-\mathrm{D} 1(50 \mathrm{ng} / \mu \mathrm{l})+\mathrm{pX}-\mathrm{PCNA}(50 \mathrm{ng} / \mu \mathrm{l})$ & 129 & 65 & 50.3 & 100.0 \\
\hline
\end{tabular}

$\mathrm{G}_{0}$ - or $\mathrm{G}_{1}$-synchronized fibroblasts were microinjected with the indicated vectors \pm rabbit IgG. Six to 12 hr after reactivation, cells were UV-irradiated, cultured for 8 additional hr in the presence of $\mathrm{BrdU}$, and processed for immunofluorescence. In the first two experiments injected cells were scored by staining with anti-rabbit IgG. In the third experiment cyclin D1-overexpressing cells were scored with a polyclonal antibody to cyclin D1. DNA repair was monitored by BrdU incorporation. Microinjection of cyclin D1 expression plasmid did not allow DNA repair. Coinjection of PCNA prevented this inhibition.

\section{Materials and methods}

\section{Immunoreagents}

The preparation, purification, and characterization of mouse monoclonal antibody (mAb) against human cyclin D1, clone
DCS-6, have been described previously (Lukas et al. 1994c). mAb HE-12 to human cyclin E (Faha et al. 1993) was provided by E. Lees. mAb PC-10 to PCNA (Waseem and Lane 1990) was from Oncogene Science, $\mathrm{mAb}$ G3-245 to human $\mathrm{pRb}$ (DeCaprio et al. 1988) and mAb G-107-196 to human cyclin D3 were from
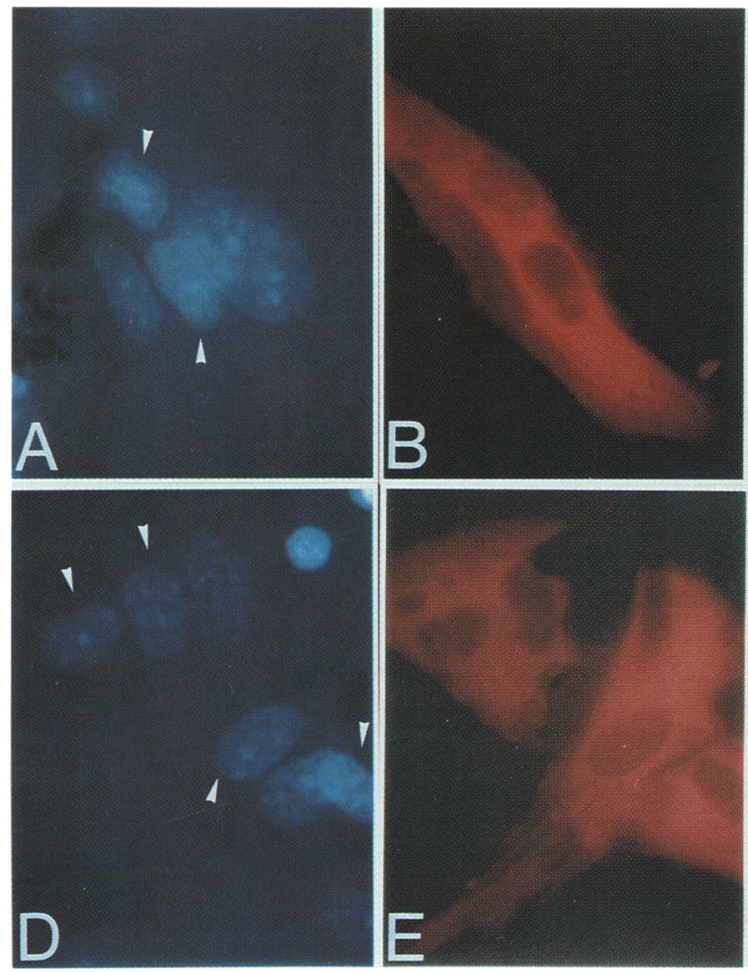
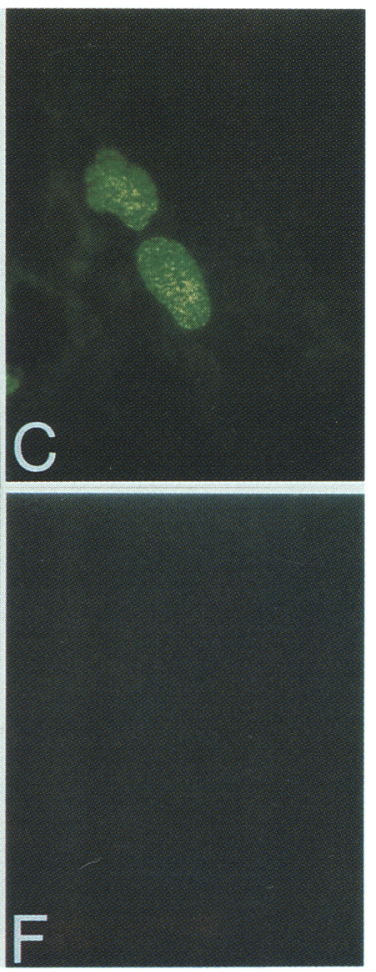

Figure 5. Cyclin D1 antisense microinjection accelerates DNA repair. $\mathrm{pX}-$ cyclin $\mathrm{Dl}$ vector plasmid $(A-C)$ or $\mathrm{pX}$ control vector $(D-F)$ was injected in synchronized $\mathrm{G}_{1}$ cells ( $\sim 6 \mathrm{hr}$ after serum readdition) together with normal affinity-purified rabbit antibody $(3 \mathrm{mg} / \mathrm{ml}$ in PBS used as a microinjection marker). Cells were irradiated $6-8$ $\mathrm{hr}$ after with an UV dose of $75 \mathrm{~J} / \mathrm{m}^{2}$. After 4 additional $\mathrm{hr}$ of incubation at $37^{\circ} \mathrm{C}$, cells were processed for immunofluorescence. Arrowheads in $A$ and $D$ indicate the position of the injected celils shown, respectively, in $B$ and $E$. 
Table 2. Effect of cyclin D1 overexpression on DNA replication

\begin{tabular}{|c|c|c|c|c|c|c|}
\hline \multirow[b]{2}{*}{ Experiment } & \multirow[b]{2}{*}{ Cell type } & \multirow[b]{2}{*}{ Injected plasmid } & \multicolumn{3}{|c|}{ Injected cells } & \multirow{2}{*}{$\begin{array}{l}\text { Noninjected } \\
\text { cells entering } \\
\text { S phase }(\%)\end{array}$} \\
\hline & & & number & $\begin{array}{l}\mathrm{BrdU}^{+} \text {cells } \\
\text { (number) }\end{array}$ & $\begin{array}{l}\text { entering } \\
\mathrm{S} \text { phase }(\%)\end{array}$ & \\
\hline \multirow[t]{5}{*}{1} & IMR-90 & $\mathrm{pX}-\mathrm{D} 1(50 \mathrm{ng} / \mu \mathrm{l})+$ vector $(50 \mathrm{ng} / \mu \mathrm{l})$ & 156 & 6 & 3.8 & 59.0 \\
\hline & IMR-90 & $\mathrm{pX}-\mathrm{Dl}(50 \mathrm{ng} / \mu \mathrm{l})+\mathrm{pX}-\mathrm{PCNA}(50 \mathrm{ng} / \mu \mathrm{l})$ & 175 & 98 & 56.0 & 66.0 \\
\hline & IMR-90 & $\mathrm{pX}-\mathrm{D} 1(50 \mathrm{ng} / \mu \mathrm{l})+\mathrm{pX}-\mathrm{Cdk} 2(50 \mathrm{ng} / \mu \mathrm{l})$ & 141 & 8 & 5.6 & 64.0 \\
\hline & IMR-90 & $\mathrm{pX}-\mathrm{D} 1(50 \mathrm{ng} / \mu \mathrm{l})+\mathrm{pX}-\mathrm{Cdk} 4(50 \mathrm{ng} / \mu \mathrm{l})$ & 155 & 3 & 1.9 & 58.0 \\
\hline & IMR-90 & vector $(100 \mathrm{ng} / \mu \mathrm{l}+$ rabbit $\mathrm{IgG})$ & 108 & 69 & 63.8 & 65.0 \\
\hline \multirow[t]{5}{*}{2} & IMR-90 & $\mathrm{pX}-\mathrm{D} 1(5 \mathrm{ng} / \mu \mathrm{l})+$ vector $(50 \mathrm{ng} / \mu \mathrm{l})$ & 89 & 5 & 5.6 & 42.0 \\
\hline & IMR-90 & $\mathrm{pX}-\mathrm{Dl}(5 \mathrm{ng} / \mu \mathrm{l})+\mathrm{pX}-\mathrm{PCNA}(5 \mathrm{ng} / \mu \mathrm{l})$ & 102 & 37 & 36.2 & 48.0 \\
\hline & IMR-90 & $\mathrm{pX}-\mathrm{Dl}(5 \mathrm{ng} / \mu \mathrm{l})+\mathrm{pX}-\mathrm{PCNA}(50 \mathrm{ng} / \mu \mathrm{l})$ & 125 & 28 & 22.4 & 48.0 \\
\hline & IMR-90 & $\mathrm{pX}-\mathrm{Dl}(5 \mathrm{ng} / \mu \mathrm{l})+\mathrm{pX}-\mathrm{Cdk} 4(50 \mathrm{ng} / \mu \mathrm{l})$ & 154 & 5 & 3.2 & 44.0 \\
\hline & IMR-90 & vector $(55 \mathrm{ng} / \mu \mathrm{l}+$ rabbit $\mathrm{IgG})$ & 83 & 40 & 48.2 & 54.0 \\
\hline \multirow[t]{4}{*}{3} & IMR-90 & $\mathrm{pX}-\mathrm{Dl}(50 \mathrm{ng} / \mu \mathrm{l})+\operatorname{vector}(50 \mathrm{ng} / \mu \mathrm{l})$ & 89 & 6 & 6.0 & 75.0 \\
\hline & IMR-90 & $\mathrm{pX}-\mathrm{Dl}(50 \mathrm{ng} / \mu \mathrm{l})+\mathrm{pX}-\mathrm{PCNA}(50 \mathrm{ng} / \mu \mathrm{l})$ & 78 & 47 & 60.2 & 78.0 \\
\hline & IMR-90 & $\mathrm{pX}-\mathrm{D} 1(50 \mathrm{ng} / \mu \mathrm{l})+\mathrm{pX}-\mathrm{Cdk} 2(50 \mathrm{ng} / \mu \mathrm{l})$ & 89 & 7 & 7.8 & 82.0 \\
\hline & IMR-90 & $\mathrm{pX}-\mathrm{Dl}(50 \mathrm{ng} / \mu \mathrm{l})+\mathrm{pX}-\mathrm{Cdk} 4(50 \mathrm{ng} / \mu \mathrm{l})$ & 92 & 4 & 4.3 & 72.0 \\
\hline \multirow[t]{3}{*}{4} & IMR-90 & $\mathrm{pX}-\mathrm{Dl}(50 \mathrm{ng} / \mu \mathrm{l})+$ vector $(50 \mathrm{ng} / \mu \mathrm{l})$ & 76 & 5 & 6.5 & 67.4 \\
\hline & IMR-90 + LT & $\mathrm{pX}-\mathrm{Dl}(50 \mathrm{ng} / \mu \mathrm{l})+\operatorname{vector}(50 \mathrm{ng} / \mu \mathrm{l})$ & 118 & 96 & 81.3 & 78.0 \\
\hline & WI-38-VA-13 & $\mathrm{pX}-\mathrm{Dl}(50 \mathrm{ng} / \mu \mathrm{l})+$ vector $(50 \mathrm{ng} / \mu \mathrm{l})$ & 123 & 104 & 84.5 & 88.5 \\
\hline
\end{tabular}

$\mathrm{G}_{1}$-synchronized cells were microinjected with the indicated vectors \pm rabbit IgG and incubated in presence of $\mathrm{BrdU}$. After $\sim 18 \mathrm{hr}$, cells were processed for immunofluorescence. Cells injected with $\mathrm{pX}-\mathrm{D} 1$ vector were scored by staining with a monoclonal antibody to cyclin D1. Cells injected with pX control vector together with rabbit IgG were scored by staining with anti-rabbit IgG. DNA replication was monitored by BrdU incorporation. Microinjection of cyclin D1 expression plasmid did not allow replicative DNA synthesis. Coinjection of PCNA prevented this inhibition.

Pharmingen, Inc. mAb C-160 to cyclin $\mathrm{A}$ has been described previously (Giordano et al. 1989).

The preparation, purification, and characterization of rabbit polyclonal antisera (pAb) against human cyclin A (Pagano et al. 1992b), human cyclin D1 (Baldin et al. 1993), human cyclin D3 (Ajchenbaum et al. 1993), human Cdk2, (Pagano et al. 1992a), and human p 21 (H. Zhang, G. Hannon, and D. Beach, in prep.) have been described previously. Rabbit pAb to $\mathrm{Cdk} 4$ was generated against a synthetic peptide HKDEGNPE carboxyl termi- nus as described (Pagano 1994). Anti-BrdU monoclonal antibody plus nuclease (ready to use) was purchased from Amersham, Inc., and anti-BrdU sheep polyclonal antibody from Fitzgerald, Inc.

\section{Cell culture and cell synchronization}

Human lung IMR-90 fibroblasts and human lung SV40 fibroblasts virus-transformed WI-38-VA13 cells were obtained from

Table 3. Effect of cyclin D1 overexpression on cell division

\begin{tabular}{|c|c|c|c|c|}
\hline \multirow[b]{2}{*}{ Experiment } & \multirow{2}{*}{$\begin{array}{l}\text { Time after } \\
\text { microinjection } \\
\text { (hr) }\end{array}$} & \multirow[b]{2}{*}{ Injected material } & \multicolumn{2}{|c|}{ Injected cells } \\
\hline & & & $\mathrm{D} 1^{+}$ & rabbit $\mathrm{IgG}^{+}$ \\
\hline \multirow[t]{6}{*}{1} & 6 & $\mathrm{pX}-\mathrm{D} 1(100 \mathrm{ng} / \mu \mathrm{l})+$ rabbit $\mathrm{IgG}$ & 73 & 108 \\
\hline & 6 & vector $(100 \mathrm{ng} / \mu \mathrm{l})+$ rabbit anti-cyclin A antibody & - & 99 \\
\hline & 6 & vector $(100 \mathrm{ng} / \mu \mathrm{l})+$ rabbit $\mathrm{IgG}$ & - & 93 \\
\hline & 24 & $\mathrm{pX}-\mathrm{D} 1(100 \mathrm{ng} / \mu \mathrm{l})+$ rabbit IgG & 102 & 156 \\
\hline & 24 & vector $(100 \mathrm{ng} / \mu \mathrm{l})+$ rabbit anti-cyclin A antibody & - & 86 \\
\hline & 24 & vector $(100 \mathrm{ng} / \mu \mathrm{l})+$ rabbit $\mathrm{IgG}$ & - & 139 \\
\hline \multirow[t]{6}{*}{2} & 6 & $\mathrm{pX}-\mathrm{Dl}(100 \mathrm{ng} / \mu \mathrm{l})+$ rabbit IgG & 70 & 110 \\
\hline & 6 & vector $(100 \mathrm{ng} / \mu \mathrm{l})+$ rabbit anti-cyclin A antibody & - & 111 \\
\hline & 6 & vector $(100 \mathrm{ng} / \mu \mathrm{l})+$ rabbit IgG & - & 93 \\
\hline & 24 & $\mathrm{pX}-\mathrm{Dl}(100 \mathrm{ng} / \mu \mathrm{l})+$ rabbit $\mathrm{IgG}$ & 101 & 160 \\
\hline & 24 & vector $\{100 \mathrm{ng} / \mu \mathrm{l}\}+$ rabbit anti-cyclin $\mathrm{A}$ antibody & - & 118 \\
\hline & 24 & vector $(100 \mathrm{ng} / \mu \mathrm{l})+$ rabbit IgG & - & 145 \\
\hline
\end{tabular}

One hundred $G_{2}$ fibroblasts for each experimental point were injected with the indicated vectors \pm rabbit IgG. Six hours after microinjection, cells were fixed and immunostained with anti-rabbit IgG to estimate the number of injected cells that survived the microinjection procedures. Twenty-four hours after microinjection cells were fixed, immunostained, and counted to determine how many of the injected cells were duplicated. Cells injected with pX-D1 vector + rabbit IgG were also costained with a monoclonal antibody to cyclin Dl to determine how many of the injected/dividing cells overexpressed D1. Microinjection of a cyclin D1 expression plasmid did not affect cell division. 


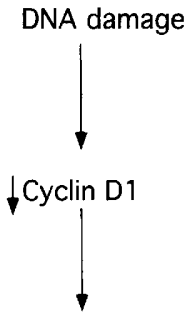

repair DNA synthesis

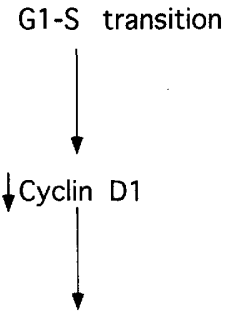

replicative DNA synthesis
Figure 6. Cyclin D1 as a negative regulator of DNA synthesis in human fibroblasts.

the American Type Culture Collection (ATCC) and cultured in Dulbecco's modified Eagle medium (DMEM) supplemented with $10 \%$ fetal calf serum (FCS), $2 \mathrm{mM}$ glutamine, $100 \mathrm{U} / \mathrm{ml}$ of penicillin, and $1 \mu \mathrm{g} / \mathrm{ml}$ of streptomycin. IMR-90+LT cells (SV40 large-T-transfected IMR-90) were provided by J.W. Shay and grown as described [previously IDH-4, (Wright et al. 1989)]. IMR-90 were obtained at PDL (population doubling) 20 and grown for not more than 40 total PDLs. Cells were counted at each passage, and the increase in PDL was calculated as the $\log _{2}$-fold increase in cell number.

Different cell types were synchronized in $G_{1}$ according to the following methods: IMR-90 cells were incubated for 2-3 days in DMEM containing $0.2 \%$ FCS. After this period, $<1 \%$ of the cell population incorporated BrdU (see Immunofluorescence and in situ extraction, below) during an incubation of $24 \mathrm{hr}$. IMR$90+\mathrm{LT}$ cells, contained a dexamethasone-inducible SV40 large- $\mathrm{T}$ antigen gene and were incubated for 2 days in the presence of $10 \%$ steroid-depleted FCS [SDFCS, obtained as described (Wright et al. 1989)/ and for 3 additional days in the presence of $0.2 \%$ SDFCS. After these periods of incubation, $<8 \%$ of the cell population (cells that are still large-T positive) incorporated BrdU during an incubation of $24 \mathrm{hr}$, as detected by immunofluorescence (Tam et al. 1994). This result correlated with cell-cycle analysis by flow cytometry, demonstrating that in these cultures $>95 \%$ of the cells presented a 2 N DNA content. Similar results have been obtained previously (Shay et al. 1992). In the experiments where IMR-90 and IMR-90 + LT were compared directly, both cell types were synchronized as described for IMR-90+LT. WI-38-VA-13 cells were synchronized in mitosis by an $18 \mathrm{hr}$ incubation in the presence of $40 \mathrm{ng} / \mathrm{ml}$ of nocodazole (Sigma). The rounded cells were subsequently detached from the substrate by gentle shaking and pipetting. After two washes in fresh, nocodazole-free DMEM, the cells were replated into fresh medium. After $4 \mathrm{hr}$, the nonattached cells were washed out. Flow cytometry demonstrated that in these cultures $>95 \%$ of the cells presented a $2 \mathrm{~N}$ DNA content until $\sim 12-14 \mathrm{hr}$ after replating. Cell cycle phases were monitored by flow cytometry (FACSCAN, Becton Dickinson) after staining cellular DNA with $50 \mu \mathrm{g} / \mathrm{ml}$ of propidium iodide (Sigma) in the presence of $10 \mu \mathrm{g} / \mathrm{ml}$ of DNase-free RNase (Boehringer Mannheim) and by BrdU incorporation (see Immunofluorescence and in situ extraction, below).

\section{UV light irradiation}

UV irradiation was performed as described (Toschi and Bravo 1988). Briefly, the medium was removed and cell monolayers growing on glass coverslips were rinsed in PBS. PBS was removed and cultures were exposed to UV light in a UVC 515
Ultraviolet Multilinker (245 nm, Ultra Lum). The UV doses were monitored with a UV intensity meter (UVP, Inc.).

\section{Extract preparation and immunoblotting}

Cell extracts were prepared as described (Pagano et al. 1993). Briefly, 3-5 volumes of lysis buffer $(50 \mathrm{~mm}$ Tris $-\mathrm{HCl}$ at $\mathrm{pH} 7.4$, $0.25 \mathrm{M} \mathrm{NaCl}, 0.1 \%$ Triton-X 100, $1 \mathrm{~mm}$ EDTA, $50 \mathrm{~mm} \mathrm{NaF}, 1$ mM DTT, $0.1 \mathrm{~mm} \mathrm{Na} \mathrm{VO}_{4}$ ) were added to pelletted cells. The following protease inhibitors were added: $0.1 \mathrm{~mm}$ phenylmethylsulfonyl fluoride (PMSF), $1 \mu \mathrm{g} / \mathrm{ml}$ of leupeptin, $10 \mu \mathrm{g} / \mathrm{ml}$ of soybean trypsin inhibitor, $10 \mu \mathrm{g} / \mathrm{ml}$ of L-1 Chlor-3-14-tosylamido)-4 Phenyl-2-butanon (TPCK), $10 \mu \mathrm{g} / \mathrm{ml}$ of L-1 Chlor-3-(4tosylamido)-7-amino-2-heptanon-hydrochloride (TLCK), and 1 $\mu \mathrm{g} / \mathrm{ml}$ of aprotinin. After incubation on ice for $30 \mathrm{~min}$, the samples were centrifuged at $14,000 \mathrm{rpm}$ in an Eppendorf microcentrifuge for $5 \mathrm{~min}$ at $4^{\circ} \mathrm{C}$ to recover a Triton-soluble fraction (supernatant). The pellet was resuspended in the original volume of the same buffer containing $1 \%$ SDS. After incubation on ice for $30 \mathrm{~min}$, samples were centrifuged at $14,000 \mathrm{rpm}$ in an Eppendorf microcentrifuge for $5 \mathrm{~min}$ at $4^{\circ} \mathrm{C}$ to recover a Tritoninsoluble fraction (supernatant). Conditions for immunoblotting have been described previously (Draetta and Beach 1988). Proteins were transferred from gel to a PVDF membrane (DuPont) by semidry blotting as described in Pagano et al. (1992b). Filters were subjected to immunoblotting using the ECL (Amersham/ detection system according to the manufacturer's instructions. Gels were scanned and bands were quantified by using a pdi laser densitometer.

\section{Kinase assays}

Kinase reactions were performed as described (Pagano et al. 1992b). Briefly, after immunoprecipitations with mAb HE-67 to cyclin $\mathrm{E}$ (Pharmingen Inc.), pellets were incubated for $5 \mathrm{~min}$ at $30^{\circ} \mathrm{C}$ in the presence of $50 \mathrm{mM}$ Tris- $\mathrm{Cl}$ at $\mathrm{pH} 7.5,10 \mathrm{mM} \mathrm{MgCl}_{2}$, $1 \mathrm{mM} \mathrm{DTT}, 50 \mu \mathrm{M} \mathrm{ATP}$, and $25 \mu \mathrm{Ci}\left[{ }^{32} \mathrm{P}\right] \mathrm{ATP}$. Histone Hl was added at $0.2 \mathrm{mg} / \mathrm{ml}$. Typically, in our standards conditions, 1 pmole of phosphate incorporated/min per $\mathrm{mg}$ of proteins is equivalent to $\sim 30,000 \mathrm{cpm}$. Nonspecific activity $(\sim 2000 \mathrm{cpm}$, obtained with preimmune sera) was subtracted from each sample.

\section{Microinjection}

Cell monolayers growing on glass coverslips (at $\sim 60 \%$ density) were microinjected with an automated microinjection system (AIS, Zeiss; Ansorge and Pepperkok 1988). All microinjection experiments were carried out in $3.5-\mathrm{cm}$ petri dishes containing $3 \mathrm{ml}$ of carbonate-free DMEM, to avoid a decrease in $\mathrm{pH}$ of the medium during the injection. Each cell was injected at a pressure between $50-$ and 150 hecta-Pascal (hPa). The computer settings for injection were angle "45," speed "10," and time of injection " $0.0 \mathrm{sec}$."

The cytomegalovirus (CMV) expression vectors were obtained by inserting the entire open reading frame of the human cyclin D1, human PCNA, human Cdk4, and human Cdk2 cDNAs in pX-plasmid as described (Baldin et al. 1993). Human cyclin Dl cDNA in the antisense orientation in $\mathrm{pX}$ plasmid has been described previously (Baldin et al. 1993). Plasmids were purified with a Promega Wizard Maxi-prep kit and injected at the indicated concentration in the presence or absence of a microinjection marker (affinity-purified normal rabbit antibody; 3 $\mathrm{mg} / \mathrm{ml}$ in PBS).

DNA synthesis was monitored by adding $\mathrm{BrdU}(100 \mu \mathrm{M}, \mathrm{Am}$ ersham) for $18-20 \mathrm{hr}$ before fixing the cells. Coverslips were 
rinsed in PBS and fixed for $10 \mathrm{~min}$ in cold $\left(-20^{\circ} \mathrm{C}\right)$ methanolacetone $(1: 1)$, washed again three times with PBS, and processed for immunofluorescence.

\section{Immunofluorescence and in situ extraction}

Cell monolayers growing on glass coverslips were rinsed in PBS and fixed for $10 \mathrm{~min}$ in cold $\left(-20^{\circ} \mathrm{C}\right)$ methanol-acetone $(1: 1)$. Fixed cells were rehydrated in PBS at room temperature and processed for cell staining. Anti-cyclin Dl ascitic fluid was diluted 1:150, anti-cyclin E hybridoma supernatants were used nondiluted, affinity-purified anti-PCNA antibody was used at $20 \mu \mathrm{g} / \mathrm{ml}$, affinity-purified anti-Cdk2 pAb was used at $12 \mu \mathrm{g} /$ $\mathrm{ml}$, anti-Cdk4 pAb was used at 1:100 dilution, and anti-cyclin A hybridoma supernatants were used nondiluted. Incubation with primary antibodies was carried out for $1 \mathrm{hr}$ in a humidified chamber. After three washes in PBS the coverslips were incubated for $30 \mathrm{~min}$ with biotinylated horse anti-mouse secondary antibody or with biotinylated horse anti-rabbit secondary antibody (Vector Laboratories, dilution 1:50). Cells were washed again three times with PBS and incubated with Texas red-conjugated streptavidin (Vector Laboratories, dilution 1:100) or FITC-conjugated streptavidin (Vector Laboratories, dilution 1: $50)$.

For BrdU staining, after the staining of the first antigen, cells were incubated for $10 \mathrm{~min}$ with $1.5 \mathrm{M} \mathrm{HCl}$, subsequently washed three times with PBS, and then incubated for $1 \mathrm{hr}$ with a solution of mouse $\mathrm{mAb}$ anti-BrdU and nuclease /undiluted, Amersham), followed by a 30-min incubation with a 1:50 dilution of anti-mouse FITC-conjugated antibody (Vector Laboratories). In double-labeling experiments, if the first antigen was detected with an anti-mouse antibody, we stained BrdU with a sheep pAb (Fitzgerald, dilution 1:50), followed by an anti-sheep FITC-conjugated antibody (Vector Laboratories, dilution 1:50) for $30 \mathrm{~min}$ or directly with a FITC-conjugated $\mathrm{mAb}$ anti-BrdU (undiluted, Becton Dickinson).

The nicks generated in the DNA chains by the UV irradiation were significant enough to allow detection of repair DNA synthesis by BrdU incorporation. However, the pattern was different from the one obtained with S-phase cells. During DNA replication, either a spotted staining, typical of cells just entering $S$ phase, or an uniform BrdU staining, typical of cells in full $S$ phase, could be observed. In both cases, the staining was extremely bright. During repair, a paler staining was observed, as already described (Lu and Lane 1993). Furthermore, the spots (foci where BrdU has been incorporated) were much more numerous but also much smaller. For this reason, the signal was amplified by a long incubation (4-8 hr) with BrdU and by staining with a solution of $\mathrm{mAb}$ anti-BrdU and nuclease (Amersham), followed by a biotinylated horse anti-mouse secondary antibody (Vector Laboratories, dilution 1:50) and FITC-conjugated streptavidin (Vector Laboratories, dilution 1:50). The same procedure in nonirradiated $G_{1}$ cells or lack of the primary $m A b$ anti-BrdU in irradiated $G_{1}$ cells did not give any signal (data not shown).

All antibody reactions were carried out at room temperature, and dilutions were made in DMEM containing $10 \%$ FCS. Counterstaining for DNA was performed by adding $1 \mu \mathrm{g} / \mathrm{ml}$ of bisbenzimide (Hoechst 33258) into the final PBS wash. Immunofluorescence samples were directly mounted in Crystal/mount medium (Biomeda Corp.). Photographs were taken using a PlanNeofluar $100 \times$ or a Plan-Neofluar $40 \times$ lens mounted on a Zeiss Axiophot Photomicroscope and a Color Video Printer Mavigraph, on Sony UPC-3010 print paper.

In situ extraction was performed as described (Mittnacht and Weinberg 1991). Briefly, cell monolayers grown on glass cover- slips were rinsed in PBS, dipped for 2 sec into double-distilled water, and immersed in ice-cold hypotonic buffer $(10 \mathrm{mM}$ HEPES- $\mathrm{KOH}$ at $\mathrm{pH} 7.9,10 \mathrm{~mm} \mathrm{KCl}, 1.5 \mathrm{~mm} \mathrm{MgCl}_{2}, 0.5 \mathrm{~mm}$ DTT, $0.1 \%$ Triton). Incubation was at $4^{\circ} \mathrm{C}$ on a slowly rocking platform for $10 \mathrm{~min}$. Extracted coverslips were fixed for $10 \mathrm{~min}$ in cold $\left(-20^{\circ} \mathrm{C}\right)$ methanol-acetone $(1: 1)$.

\section{Acknowledgments}

We are grateful to A. Dutta, J. Gyuris, X. Lu, J. Lukas, and C. Sherr for helpful discussion. We thank D. Beach for a Cdk4 plasmid and for anti-p21 antibody, R. Bravo for a PCNA plasmid, E. Lees for anti-cyclin E antibody, J.W. Shay for IMR$90+$ LT cells, L. Dickinson for constructing the PCNA and the Cdk4 expression vectors, and V. Berlin, I. Chiu, S. Glass, and L. Lamphere for critically reading the manuscript. This work was supported in part by the Human Science Frontier Program grant (RG-496/93).

The publication costs of this article were defrayed in part by payment of page charges. This article must therefore be hereby marked "advertisement" in accordance with 18 USC section 1734 solely to indicate this fact.

\section{References}

Ajchenbaum, F., K. Ando, J.A. DeCaprio, and J.D. Griffin. 1993. Independent regulation of human D-type cyclin gene expression during Gl phase in primary human t lymphocytes. $I$. Biol. Chem. 268: 4113-4119.

Ansorge, W. and R. Pepperkok. 1988. Performance of an automated system for capillary microinjection into living cells. J. Biochem. Biophys. Methods. 16: 283-292.

Baldin, V., J. Lukas, M.J. Marcote, M. Pagano, and G. Draetta. 1993. Cyclin D1 is a nuclear protein required for cell cycle progression in $\mathrm{G}_{1}$. Genes \& Dev. 7: 812-821.

Bates, S., L. Bonetta, D. MacAllan, D. Parry, A. Holder, C. Dickson, and G. Peters. 1994. Cdk6 (PLSTIRE) and Cdk4 (PSK-J3) are distinct subset of the cyclin-dependent kinases that associate with cyclin D1. Oncogene 9: 71-79.

Blow, J.J. and P. Nurse. 1990. A cdc2-like protein is involved in the initiation of DNA replication in Xenopus egg extracts. Cell 62: 855-862.

Bravo, R. and H. Macdonald-Bravo. 1987. Existence of two populations of cyclin/proliferating cell nuclear antigen during the cell cycle: Association with DNA replication sites. $f$. Cell Biol. 105: 1549-1554.

Bravo, R., R. Frank, P.A. Blundell, and H. Macdonald-Bravo. 1987. Cyclin/PCNA is the auxiliary protein of DNA polymerase- $\delta$. Nature 326: 515-517.

Cardoso, M.C., H. Leonhardt, and B. Nadal-Ginard. 1993. Reversal of terminal differentiation and control of DNA replication: Cyclin A and Cdk2 specifically localize at subnuclear sites of DNA replication. Cell 74: 979-992.

Celis, J. and P. Madsen. 1986. Increased nuclear cyclin/PCNA antigen staining of non S-phase transformed human amnion cells engaged in nucleotide excision repair. FEBS Lett. 209: $277-283$.

Celis, J., P. Madsen, A. Celis, H. Nielsen, and B. Gesser. 1987. Cyclin (PCNA, auxiliary protein of DNA polymerase $\delta$ ) is a central component of the pathway(s) leading to DNA replication and cell division. FEBS Lett. 220: 1-7.

Datta, R., R. Hass, H. Gunji, R. Weichselbaum, and D. Kufe. 1992. Down-regulation of cell cycle genes by ionizing radiation. Cell Growth Differ. 3: 637-644.

DeCaprio, J.A., J.W. Ludlow, J. Figge, J.Y. Shew, C.M. Huang, 
W.H. Lee, E. Marsilio, E. Paucha, and D.M. Livingston. 1988. SV40 large tumor antigen forms a specific complex with the product of the retinoblastoma susceptibility gene. Cell 54: 275-283.

Draetta, G. and D. Beach. 1988. Activation of cdc2 protein kinase during mitosis in human cells: Cell cycle-dependent phosphorylation and subunit rearrangement. Cell 54: 17-26.

Draetta, G., F. Luca, J. Westendorf, L. Brizuela, J. Ruderman, and D. Beach. 1989. cdc2 protein kinase is complexed with both cyclin A and B: Evidence for proteolytic inactivation of MPF. Cell 56: 829-838.

Dulic, V., E. Lees, and S. Reed I. 1992. Association of human cyclin $\mathrm{E}$ with a periodic Gl-S phase protein kinase. Science 257: 1958-1961.

Dulic, V., L. Drullinger, E. Lees, S. Reed, and G. Stein. 1993. Altered regulation of $\mathrm{Gl}$ cyclins in senescent human diploid fibroblasts: Accumulation of inactive cyclin E-Cdk2 and cyclin D1-Cdk2 complexes. Proc. Natl. Acad. Sci. 90: 1103411038.

Dulic, V., W. Kaufmann, S. Wilson, T. Tlsty, E. Lees, W. Harper, S. Elledge, and S. Reed. 1994. p53-dependent inhibition of cyclin-dependent kinase activities in human fibroblasts during radiation-induced G1 arrest. Cell 76: 1013-1023.

D'Urso, G., R. Marraccino, D. Marshak, and J. Roberts. 1990. Cell cycle control of DNA replication by a homologue from human cells of the $\mathrm{p} 34 \mathrm{cdc} 2$ protein kinase. Science 250: 786-791.

Dutta, A. and B. Stillman. 1992. cdc2 family kinases phosphorylate a human cell DNA replication factor, RPA, and activate DNA replication. EMBO I. 11: 2189-2199.

Dutta, A., S. Din, S.J. Brill, and B. Stillman. 1991. Phosphorylation of replication protein A: A role for cdc2 kinase in G1/S regulation. Cold Spring Harbor Symp. Quant. Biol. 56: 315324.

El-Deiry, W.S., T. Tokino, V.E. Velculescu, D.B. Levy, R. Parsons, J.M. Trent, D. Lin, W.E. Mercer, K.W. Kinzler, and B. Vogelstein. 1993. WAF1, a potential mediator of p53 tumor suppression. Cell 75: 817-825.

Ewen, M., H. Sluss, L. Whitehouse, and D. Livingston. 1993a. TGF $\beta$ inhibition of cdk4 synthesis is linked to cell cycle arrest. Cell 74: 1009-1020.

Ewen, M.E., H.K. Sluss, C.J. Sherr, H. Matsushime, J.Y. Kato, and D.M. Livingston. 1993b. Functional interaction of the retinoblastoma protein with mammalian d-type cyclins. Cell 73: 487-497.

Faha, B., E. Harlow, and E. Lees. 1993. The adenovirus E1Aassociated kinase consists of cyclin E-p33cdk2 and cyclin A-p33cdk2. I. Virol. 67: 2456-2465.

Fang, F. and J. Newport. 1991. Evidence that the G1-S and the G2-M transitions are controlled by different cdc2 proteins in higher eukaryotes. Cell 66: 731-742.

Fotedar, R. and J.M. Roberts. 1991. Association of p34cdc2 with replicating DNA. Cold Spring Harbor Symp. Quant. Biol. 56: 325-333.

Freeman, R., S. Estus, and J.E. Johnson. 1994. Analysis of cell cycle related gene expression in postmitotic neurons: Selective induction of cyclin D1 during programmed cell death. Neuron 12: 1-20.

Gallant, P. and E. Nigg. 1992. Cyclin B2 undergoes cell cycle dependent nuclear translocation and, when expressed as a nondestructible mutant, causes mitotic arrest in HeLa cells. I. Cell Biol. 117: 213-224.

Giordano, A., P. Whyte, E. Harlow, B.R. Franza, D. Beach, and

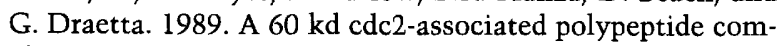
plexes with the ElA proteins in adenovirus-infected cells. Cell 58: 981-990.
Girard, F., U. Strausfeld, A. Fernandez, and N. Lamb. 1991. Cyclin $A$ is required for the onset of DNA replication in mammalian fibroblasts. Cell 67: 1169-1179.

Glotzer, M., A. Murray, and M. Kirschner. 1990. Cyclin is degraded by the ubiquitin pathway. Nature 349 : 132-138.

Gu, Y., C. Turck, and D. Morgan. 1993. Inhibition of Cdk2 activity in vivo by an associated $20 \mathrm{~K}$ regulatory subunit. Nature 366: 707-710.

Guadagno, T., M. Ohtsubo, J. Roberts, and R. Assoian. 1993. A link between cyclin A expression and adhesion-dependent cell cycle progression. Science 262: 1572-1575.

Harper, J.W., G.R. Adami, N. Wei, K. Keyomarsi, and S.J. Elledge. 1993. The p21 Cdk-interacting protein Cipl is a potent inhibitor of G1 cyclin-dependent kinases. Cell 75: 805-816.

Hartwell, L.H. 1974. Saccharomyces cerevisiae cell cycle. Bacteriol. Rev. 38: 164-198.

Hinds, P., S. Dowdy, E. Ng-Eaton, A. Arnold, and R. Weinberg. 1994. Function of a human cyclin as an oncogene. Proc. Natl. Acad. Sci. 91: 709-713.

Jaskulski, D., J.K. deRiel, W.E. Mercer, B. Calabretta, and R. Baserga. 1988. Inhibition of cellular proliferation by antisense oligodeoxynucleotides to PCNA cyclin. Science 240: 1544-1566.

Jiang, W., S.M. Kahn, P. Zhou, Y. Zhang, A.M. Cacace, A.S. Infante, S. Doi, R.M. Santella, and I.B. Weinstein. 1993. Overexpression of cyclin D1 in rat fibroblasts causes abnormalities in growth control, cell cycle progression and gene expression. Oncogene 8: 3447-3457.

Kastan, M., O. Onyekwere, W. El-Deiry, D. Sidransky, B. Volgelstein, and R. Craig. 1991. Participation of p53 in the cellular response to DNA damage. Cancer Res. 51: 6304-6311.

Kastan, M., Q. Zhan, W. El-Deiry, F. Carrier, T. Jacks, W. Walsh, B. Plunkett, B. Volgelstein, and A. Fornace. 1992. A mammalian cell cycle checkpoint pathway utilizing p53 and GADD45 is defective in ataxia-telanbiectasia. Cell 71: 587597.

Kato, J., H. Matsushime, S.W. Hiebert, M.E. Ewen, and C.J. Sherr. 1993. Direct binding of cyclin D to the retinoblastoma product $(\mathrm{pRb})$ and $\mathrm{pRb}$ phosphorylation by the cyclin D-dependent kinase CDK4. Genes \& Dev. 7: 331-342.

Knoblich, J., K. Sauer, L. Jones, H. Richardson, R. Saint, and C. Lehener. 1994. Cyclin E controls $S$ phase progression and its down-regulation during Drosophila embryogenesis is required for the arrest of cell proliferation. Cell 77: 107-120.

Koff, A., F. Cross, A. Fisher, J. Schumacher, K. Leguellec, M. Philippe, and J.M. Roberts. 1991. Human cyclin E, a new cyclin that interacts with two members of the CDC2 gene family. Cell 66: 1217-1228.

Kuerbitz, S., B. Plunkett, W. Walsh, and M. Kastan. 1992. Wildtype p53 is a cell cycle checkpoint determinant following irradiation. Proc. Natl. Acad. Sci. 89: 7491-7495.

Lee, S., A. Kwong, Z. Pan, and J. Hurwitz. 1991. Studies on the activator 1 protein complex, an accessory factor for proliferating cell nuclear antigen-dependent DNA polymerase $\delta$. $I$. Biol. Chem. 266: 594-602.

Lee, S., Z. Pan, A. Kwong, P. Burges, and Hurwitz. 1992. Synthesis of DNA polymerase $\epsilon$ in vitro. I. Biol. Chem. 266: 22707-22717.

Lehner, C.F., N. Yakubovich, and P.H. O'Farrell. 1991. Exploring the role of drosophila cyclin $A$ in the regulation of $S$ phase. Cold Spring Harbor Symp. Quant. Biol. 56 465-475.

Lew, D.J., V. Dulic, and S.I. Reed. 1991. Isolation of three novel human cyclins by rescue of $\mathrm{Gl}$ cyclin (cln) function in yeast. Cell 66: 1197-1206.

Lovec, H., A. Sewing, F. Lucibello, R. Mueller, and T. Moroy. 
1994. Oncogenic activity of cyclin D1 revealed through cooperation with Ha-ras: Link between cell cycle control and malignant transformation. Oncogene 9: 323-326.

Lu, X. and D.P. Lane. 1993. Differential induction of transcriptionally active $\mathrm{p} 53$ following UV or ionizing radiation: Defects in chromosome instability syndromes? Cell 75: 765778.

Luca, F., E. Shibuya, C. Dohrmann, and J. Ruderman. 1991. Both cyclin $A \Delta 60$ and $B \Delta 97$ are stable and arrest cells in M-phase, but only cyclin B $\Delta 97$ turns on cyclin destruction. EMBO I. 10: $4311-4320$.

Lucibello, F., A. Sewing, S. Brusselbach, C. Burger, and R. Muller. 1993. Deregulation of cyclin D1 and $\mathrm{E}$ and suppression of Cdk2 and Cdk4 in senescent human fibroblasts. I. Cell Sci. 105: 123-133.

Lukas, J., D. Jadayel, J. Bartkova, E. Nakeva, M. Dyer, M. Strauss, and J. Bartek. 1994a. BCL-1/cyclin DI oncoprotein oscillates and subverts the Gl phase control in B-cell neoplasm carrying the $t(11 ; 14)$ translocation. Oncogene (in press).

Lukas, J., H. Müller, J. Bartkova, D. Spitkovsky, A. Kjerulff, P. Jansen-Durr, M. Strauss, and J. Bartek. 1994b. DNA tumor virus oncoproteins and retinoblastoma gene mutations share the ability to relieve the cell's requirement for cyclin DI function in G1. J. Cell Biol. 125: 625-638.

Lukas, J., M. Pagano, Z. Staskova, G. Draetta, and J. Bartek. 1994c. Cyclin Dl protein oscillates and is essential for cell cycle progression in human tumor cell lines. Oncogene 9: 707-718.

Matsuoka, S., M. Yamaguchi, and A. Matsukage. 1994. D-type cyclin-binding regions of proliferating cell nuclear antigen. $/$. Biol. Chem. 269: 11030-11036.

Matsushime, H., M. Roussel, R. Ashmun, and C.J. Sherr. 1991a. Colony-stimulating Factor 1 regulates novel cyclins during the G1 phase of the cell cycle. Cell 65: 701-713.

Matsushime, H., M.F. Roussel, and C.J. Sherr. 1991b. Novel mammalian cyclins (CYL genes) expressed during $\mathrm{G}_{1}$. Cold Spring Harbor Symp. Quant. Biol. 56: 69-74.

Matsushime, H., M. Ewen, D.K. Strom, J.Y. Kato, S.K. Hanks, M. Roussel, and C.J. Sherr. 1992. Identification and properties of an atypical catalytic subunit p34 ${ }^{\text {PSK-J3 }}$ for mammalian D-type G1 cyclins. Cell 71: 323-334.

Matsushime, H., D.E. Quelle, S.A. Shurtleff, M. Shibuya, C.J. Sherr, and J. Kato. 1994. D-type cyclin-dependent kinase activity in mammalian cells. Mol. Cell. Biol. 14: 2066-2076.

Meyerson, M. and E. Harlow. 1994. Identification of G1 kinase activity for cdk6, a novel cyclin D partner. Mol. Cell Biol. 14: $2077-2086$.

Mittnacht, S. and R. Weinberg. 1991. Gl/S Phosphorylation of the retinoblastoma protein is associated with an altered affinity for the nuclear compartment. Cell 65: 381-393.

Motokura, T. and A. Arnold. 1993. Cyclin D and oncogenesis. Curr. Opin. Genet. Dev. 3: 5-10.

Motokura, T., T. Bloom, Y.G. Kim, H. Jueppner, J. Ruderman, H. Kronenberg, and A. Arnold. 1991. A novel cyclin encoded by a bcll-linked candidate oncogene. Nature 350: 512-515.

Motokura, T., K. Keyomarsi, H. Kronenberg, and A. Arnold. 1992. Cloning and characterization of human cyclin D3, a cDNA closely related in sequence to the PRADl/cyclin D1 proto-oncogene. J. Biol. Chem. 267: 20412-20415.

Murray, A.W., M.J. Solomon, and M.W. Kirschner. 1989. The role of cyclin synthesis and degradation in the control of maturation promoting factor activity. Nature 339: 280-286.

Muschel, R., H. Zhang, and G. McKenna. 1993. Differential effect of ionizing radiation on the expression of cyclin $A$ and cyclin B in HeLa cells. Cancer Res. 53: 1128-1135.
Musgrove, E.A., J.A. Hamilton, C.S.L. Lee, K.J.E. Sweeney, C.K.W. Watts, and S.R.L. 1993. Growth factor, steroid, and steroid antagonist regulation of cyclin gene expression associated with changes in T-47D human breast cancer cell cycle progression. Mol. Cell. Biol. 13: 3577-3587.

Noda, A., Y. Ning, S. Venable, O. Pereira-Smith, and J.R. Smith. 1994. Exp. Cell. Res. 211: 90-98.

Ohtsubo, M. and J. Roberts. 1993. Cyclin-dependent regulation of G1 in mammalian fibroblasts. Science 259: 1908-1912.

Pagano, M. 1994. Cell Cycle: Materials and methods. SpringerVerlag. (In press).

Pagano, M., G. Draetta, and P. Jansen-Dürr. 1992a. Association of cdk2 kinase with the transcription factor E2F during $S$ phase. Science 255: 1144-1147.

Pagano, M., R. Pepperkok, F. Verde, W. Ansorge, and G. Draetta. $1992 \mathrm{~b}$. Cyclin A is required at two points in the human cell cycle. $E M B O$ I. 11: 761-771.

Pagano, M., R. Pepperkok, J. Lukas, V. Baldin, W. Ansorge, J. Bartek, and G. Draetta. 1993. Regulation of the human cell cycle by the cdk2 protein kinase. J. Cell Biol. 121: 101-111.

Pardee, A.B. 1989. Gl events and regulation of cell proliferation. Science 246: 603-614.

Prelich, G., M. Kostura, D.R. Marshak, M.B. Mathews, and B. Stillman. 1987a. The cell-cycle regulated proliferating cell nuclear antigen is required for SV40 DNA replication in vitro. Nature 326: 471-475.

Prelich, G., C.-K. Tan, M. Kostura, M.B. Mathews, A.G. So, K.M. Downey, and B. Stillman. 1987b. Functional identity of proliferating cell nuclear antigen and a DNA polymerase- $\delta$ auxiliary protein. Nature 326: 517-520.

Quelle, D., R. Ashmun, S. Shurtleff, J. Kato, D. Bar-Sagi, M. Roussel, and C. Sherr. 1993. Overexpression of mouse D-type cyclins accelerates $G_{1}$ phase in rodent fibroblasts. Genes \& Dev. 7: 1559-1571.

Resnitzky, D., M. Gossen, H. Bujard, and S. Reed. 1994. Acceleration of the Gl/S phase transition by expression of cyclin $\mathrm{D} 1$ and $\mathrm{E}$ with an inducible system. Mol. Cell. Biol. 14: $1669-1679$.

Serrano, M., G.J. Hannon, and D. Beach. 1993. A new regulatory motif in cell-cycle control causing specific inhibition of cyclin D/Cdk4. Nature 366: 704-707.

Sewing, A., C. Burger, S. Brusselbach, C. Schalk, F. Lucibello, and R. Muller. 1993. Human cyclin D1 encodes a labile nuclear protein whose synthesis is directly induced by growth factors and suppressed by cyclic AMP. J. Cell Sci. 104: 545554.

Shay, J., M. West, and W. Wright. 1992. Re-expression of senescent markers in deinduced reversibly immortalized cells. Exp. Gerontol. 27: 477-492.

Sherr, C.J. 1993. Mammalian Gl cyclins. Cell 73: 1059-1065.

1994. The ins and outs of Rb: Coupling gene expression to the cell cycle clock. Trends Cell Biol. 4: 15-18.

Shivii, M.K.K., M.K. Kenny, and R.D. Wood. 1992. Proliferating cell nuclear antigen is required for DNA excision repair. Cell 69: $367-374$.

Sobczak-Thepot, J., F. Harper, F. Florentin, Y. Zindy, C. Brechot, and E. Puvion. 1993. Localization of cyclin A at the sites of cellular DNA replication. Exp. Cell Res. 206: 43-48.

Tam, S.W., A.M. Theodoras, J.W. Shay, G.F. Draetta, and M. Pagano. 1994. Differential expression and regulation of cyclin D1 protein in normal and tumor human cells: Association with Cdk4 is required for cyclin D1 function in G1 progression. Oncogene 9: (in press).

Toschi, L. and R. Bravo. 1988. Changes in cyclin/PCNA distribution during DNA repair synthesis. J. Cell Biol. 107: 16231628. 
Tsai, L., E. Lees, B. Faha, E. Harlow, and K. Riabowol. 1993a. The cdk2 kinase is required for the $\mathrm{G} 1$ to $\mathrm{S}$ transition in mammalian cells. Oncogene 8: 1593-1602.

Tsai, L., T. Takahashi, V. Caviness, and E. Harlow. 1993b. Activity and expression pattern of cyclin-dependent -kinase 5 in embryonic mouse nervous system. Development 119: $1029-1040$.

van den Heuvel, S. and E. Harlow. 1993. Distinct roles for cyclin-dependent kinases in cell cycle control. Science 262: 2050-2054.

Waseem, N. and D. Lane. 1990. Monoclonal antibody analysis of the proliferating cell nuclear antigen (PCNA). J. Cell Sci. 96: $121-129$.

Winston, J. and W. Pledger. 1993. Growth factor regulation of cyclin D1 mRNA expression through protein synthesis-dependent and -independent mechanisms. Mol. Biol. Cell 4: $1133-1144$.

Won, K., Y. Xiong, D. Beach, and M. Gilman. 1992. Growthregulated expression of $\mathrm{D}$-type cyclin genes in human diploid fibroblast. Proc. Natl. Acad. Sci. 89: 9910-9914.

Wright, W., O. Pereira-Smith, and J. Shay. 1989. Reversible cellular senescence: Implications for immortalization of normal human diploid fibroblasts. Mol. Cell. Biol. 9: 30883092.

Xiong, Y., H. Zhang, and D. Beach. 1992. D Type cyclins associate with multiple protein kinases and the DNA replication and repair factor PCNA. Cell 71: 504-514.

1993a. Subunit rearrangement of the cyclin dependent kinases is associated with cellular transformation. Genes \& Dev. 7: 1572-1583.

Xiong, Y., G. Hannon, H. Zhang, D. Casso, R. Kobayashi, and D. Beach. 1993b. p21 is a universal inhibitor of the cyclin kinases. Nature 366: 701-704.

Zhang, H., Y. Xiong, and D. Beach. 1993. PCNA and p21 are universal elements of the cell cycle kinase family. Mol. Biol. Cell 4: 897-906.

Zindy, F., E. Lamas, X. Chenivesse, J. Sobczak, J. Wang, D. Fesquet, B. Henglein, and C. Brechot. 1992. Cyclin A is required in S phase in normal epithelial cells. Biochem. Biophys. Res. Commun. 182: 1144-1154. 


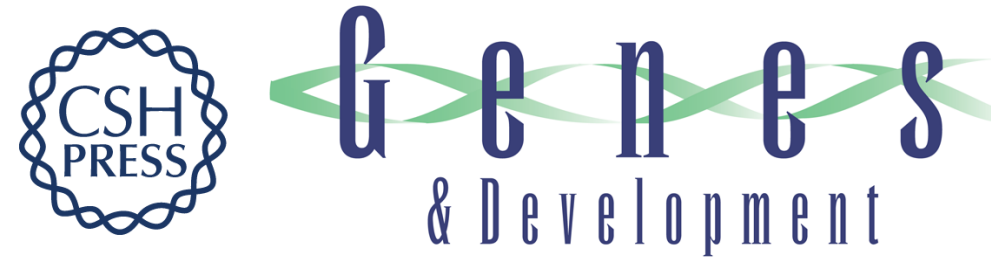

\section{Cyclin D1-mediated inhibition of repair and replicative DNA synthesis in human fibroblasts.}

M Pagano, A M Theodoras, S W Tam, et al.

Genes Dev. 1994, 8:

Access the most recent version at doi:10.1101/gad.8.14.1627

References This article cites 97 articles, 44 of which can be accessed free at:

http://genesdev.cshlp.org/content/8/14/1627.full.html\#ref-list-1

License

Email Alerting

Service

Receive free email alerts when new articles cite this article - sign up in the box at the top right corner of the article or click here.

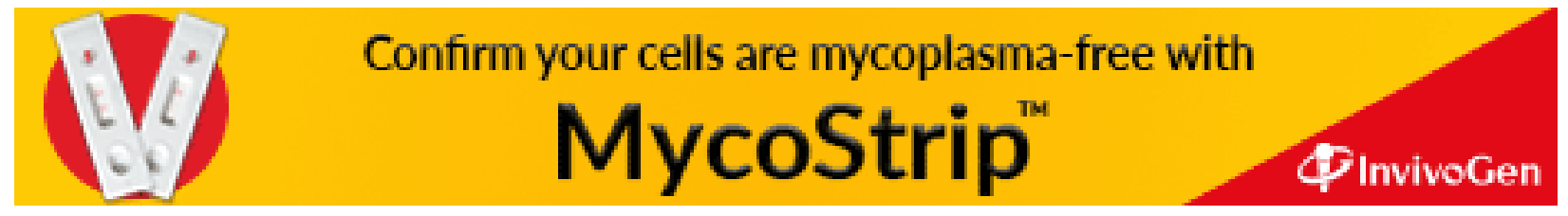

